\title{
Mesozoic tectonic evolution of the South Orkney Microcontinent, Scotia arc, Antarctica
}

\author{
R. A. J. TROUW*, C. W. PASSCHIER†, L. S. A. SIMÕESł, R. R. ANDREIS* \\ \& C. M. VALERIANO§ \\ * Departamento de Geologia, I.GEO, UFRJ, 21910-900,Rio de Janeiro, RJ, Brazil \\ $\dagger$ Institut für Geowissenschaften, Gutenberg Universität, 55099 Mainz, Germany \\ † Departamento de Geologia, UNESP, 13506-900,Rio Claro, SP, Brazil \\ $\S$ Departamento de Geologia, UERJ, Rio de Janeiro, RJ, Brazil
}

(Received 6 June 1996; accepted 13 January 1997)

\begin{abstract}
The South Orkney Islands are the exposed part of a continental fragment on the southern limb of the Scotia arc. The islands are to a large extent composed of metapelites and metagreywackes of probable Triassic sedimentary age. Deformation related to an accretionary wedge setting, with associated metamorphism from anchizone to the greenschist facies, are of Jurassic age (176-200 Ma). On Powell Island, in the centre of the archipelago, five phases of deformation are recognized. The first three, associated with the main metamorphism, are tentatively correlated with early Jurassic subduction along the Pacific margin of Gondwana. $\mathrm{D}_{4}$ is a phase of middle to late Jurassic crustal extension associated with uplift. This extension phase may be related to opening of the Rocas Verdes basin in southern Chile, associated with the breakup of Gondwanaland. Upper Jurassic conglomerates cover the metamorphic rocks unconformably. $\mathrm{D}_{5}$ is a phase of brittle extensional faulting probably associated with Cenozoic opening of the Powell basin west of the archipelago, and with development of the Scotia arc.
\end{abstract}

\section{Introduction}

The South Orkney Islands are located at $60^{\circ} 35^{\prime} \mathrm{S}$, $45^{\circ} 00^{\prime} \mathrm{W}$ on the south side of the Scotia arc, between South America and the Antarctic Peninsula (Fig. 1). The islands are the only exposed part of a microcontinent known as the South Orkney Microcontinent (SOM) (Dalziel, 1984; Barker, Dalziel \& Storey, 1991). The SOM is one of several continental fragments that form both the North and South Scotia ridges (Fig. 1) (Dalziel, 1984; King \& Barker, 1988; Barker, Dalziel \& Storey, 1991; King et al. 1994). These fragments are part of a once continuous active plate margin of Gondwanaland and were brought into their present position by differential relative motion of southern South America and the Antarctic Peninsula (Cunningham et al. 1995) and by back-arc spreading in the Scotia arc within the past 40 Ma (Barker, Dalziel \& Storey, 1991). This spreading formed the Scotia and Sandwich plates and seems to have occurred, during the last $8 \mathrm{Ma}$ before present, in response to rapid eastward roll-back of the hinge of a subduction zone that preceded the present South Sandwich arc (Fig. 1); active spreading is still taking place behind this arc in response to westward subduction of the South American plate (Barker, Dalziel \& Storey, 1991). The SOM is separated from the Scotia plate in the north by an active sinistral transform fault; in the west and east it is bounded by small extensional oceanic basins, the Powell and Jane basins, and in the south by the Weddell basin (Barker, Barber \& King, 1984; King \& Barker, 1988; Lawver, della Vedova \& von Herzen, 1991; Barker, Dalziel \&
Storey, 1991). The southwest margin of the SOM may be a strike-slip fault parallel to the sinistral transform boundary to the north (King \& Barker, 1988). A narrow ridge probably of extended continental crust, the South Scotia Ridge, connects the SOM with the continental crust of the Antarctic Peninsula (Galindo-Zaldivar et al. 1994).

Although the SOM is relatively small and only one of many continental fragments in the Scotia Arc region, its tectonic history is of more than local interest. The South Orkney Islands are mainly composed of metasedimentary and meta-igneous rocks that accumulated on the Pacific margin of Gondwanaland prior to Gondwana breakup, and little is known about the tectonic regime that existed during this period in West Antarctica. Gondwana breakup, initiated in this region by the separation of an Andean/Antarctic Peninsula magmatic arc from the remainder of South America, during late Jurassic and early Cretaceous times, led to the opening of the Weddell sea (Barker, Dalziel \& Storey, 1991; King, Livermore \& Storey, 1996; DiVenere, Kent \& Dalziel, 1996). Finally, the Scotia arc formed a continuous connection between Antarctica and South America after Gondwana breakup until c. $30 \mathrm{Ma}$, and prevented establishment of the circumpolar current with its consequences for the climate in the southern hemisphere until that time (Barker, Dalziel \& Storey, 1991). The connection disintegrated during initial stages of the development of active spreading centres in the western Scotia Sea (Barker \& Burrell, 1977; Cunningham et al. 1995), but details 
of this breakup are not well known. Since the SOM was situated in the region where disintegration started, its tectonic history may help to clarify the evolution of the Scotia arc as a whole.

\section{Regional geology}

The South Orkney Islands are composed of five major and a large number of smaller islands. The principal islands are Coronation, Powell, Fredriksen, Laurie and Signy (Fig. 1b). The islands have a relatively steep relief with a maximum elevation of about $1000 \mathrm{~m}$, and nearly $90 \%$ of the surface is covered by glaciers.

The islands are composed of three major rock units (Fig. 1b) (Thomson, 1973, 1974; Dalziel, 1984): (i) the metamorphic complex, underlying Coronation, Signy and northern Powell islands; (ii) the GreywackeShale Formation (Thomson, 1973) cropping out on Laurie and surrounding islands, and at southern Powell Island; and (iii) the Spence Harbour and Powell Island conglomerates (Thomson, 1973; Elliot \& Wells, 1982; Wells, 1984).

The metamorphic rocks are part of the Scotia metamorphic complex (Tanner, Pankhurst \& Hyden, 1982; Dalziel, 1982, 1984) that has been interpreted as a Mesozoic-Cenozoic subduction complex generated by the subduction of Pacific Ocean floor (Smellie \& Clarkson, 1975; Dalziel, 1984; Meneilly \& Storey, 1986). The complex is defined by metamorphic criteria and may therefore include rocks of different age and protolith. At the South Orkney Islands, radiometric age dating ( $\mathrm{K}-\mathrm{Ar}$, $\mathrm{Rb}-\mathrm{Sr}$ ) indicates that the metamorphism occurred between 205 and $176 \mathrm{Ma}$ (early to middle Jurassic: Miller, 1960; Grikurov, Krylov \& Silin, 1967; Tanner, Pankhurst \& Hyden, 1982; Grunow et al. 1992).

The Greywacke-Shale Formation is mainly composed of stratified successions, interpreted as submarine fan deposits resulting from turbidity current processes. This formation is considered to be an equivalent of the Trinity Peninsula Group from the Antarctic Peninsula (e.g. Dalziel, 1984), with similar lithofacies and environmental interpretation (Smellie, 1991; Paciullo, Andreis \& Ribeiro, 1994; Ribeiro et al. 1994). The Trinity Peninsula Group and its correlatives have been ascribed a presumed Permo-Triassic age (Smellie, 1991), but fossil content (Thomson, 1975; Dalziel et al. 1981) and most Rb-Sr age determinations (Willan, Pankhurst \& Hervé, 1994; Trouw, Pankhurst \& Ribeiro, 1997) point to a Triassic rather than a Permian sedimentation age.

The Spence Harbour and Powell Island conglomerates cover both of the above mentioned units unconformably. They are almost entirely composed of coarse debris derived from these units and were interpreted as alluvial fan deposits (Elliot \& Wells, 1982; Wells, 1984). Fossils indicate an early Cretaceous age for the Spence Harbour Conglomerate and a late Jurassic-early Cretaceous age for the Powell Island Conglomerate (Thomson, 1981).

Thomson $(1973,1974)$ published general descriptions of the geology of Powell and Coronation islands. Storey $\&$ Meneilly (1985) discussed the paragenesis of metamorphic rocks from Signy Island (Fig. 1b), including whole rock and mineral chemistry data, confirming that they were formed in a subduction complex setting. The tectonic transport recorded in the rocks of this island was deduced to be top towards the north-northwest along flat-lying foliation surfaces (Meneilly \& Storey, 1986).

Dalziel (1984) described the structure of the whole archipelago in detail; he drew attention to the fact that the only known contact between the Scotia metamorphic complex and the pre-late Jurassic sedimentary sequences (Greywacke-Shale Formation, Trinity Peninsula Group) occurs on Powell Island. For this reason Powell Island was chosen for detailed study during the 8th and 10th Brazilian Expeditions to Antarctica, in the austral summers of $1989 / 90$ and 1991/92. This paper presents new data on Powell and neighbouring islands, and discusses the implications for reconstructions of the Mesozoic tectonic evolution of the Scotia arc region. The data are derived from a total of 23 field stations shown in Figures $1 \mathrm{~b}$ and 2 . These stations were visited either by inflatable boat or by helicopter; at each station a detailed analysis of the structure was made and samples were collected.

\section{Lithotypes and protoliths}

\section{3.a. Powell Island}

The present account of the geology of Powell Island is mainly based on the analysis of outcrops along the coast. The topography of the 1:100000 sheet (British Antarctic Survey, 1988) is inaccurate and was corrected where possible (Fig. 2). On previously published maps of Powell Island (e.g. Dalziel, 1984) all three rock units mentioned in the introduction are present (Fig. 1b), and this is, in a way, correct. However, our study confirms that a gradual metamorphic and structural transition occurs between the low grade Greywacke-Shale Formation in the south and higher grade 'metamorphic complex' rocks in the north. This possibility was already postulated by Thomson (1973) and by Dalziel (1984), who discussed the transition in detail. Dalziel (1984) reached the conclusion that it is a transition "(1) in a structural sense, the same foliation gradually becomes more penetrative northward into the metamorphic complex; (2) in a metamorphic sense, the grade and degree of recrystallization increase northward, and (3) also in a lithologic sense...". In our understanding the lithological transition is only of local importance, as further explained in the next paragraph. This means that in our view the transition is a zone through which the Greywacke-Shale Formation rocks become gradually more deformed and metamorphosed towards the the north. It therefore does not justify a lithological contact on the map (Fig. 2).

At southern Powell Island (PO-1; Fig. 2) metasandand siltstones appear more or less regularly interlayered 
(a)

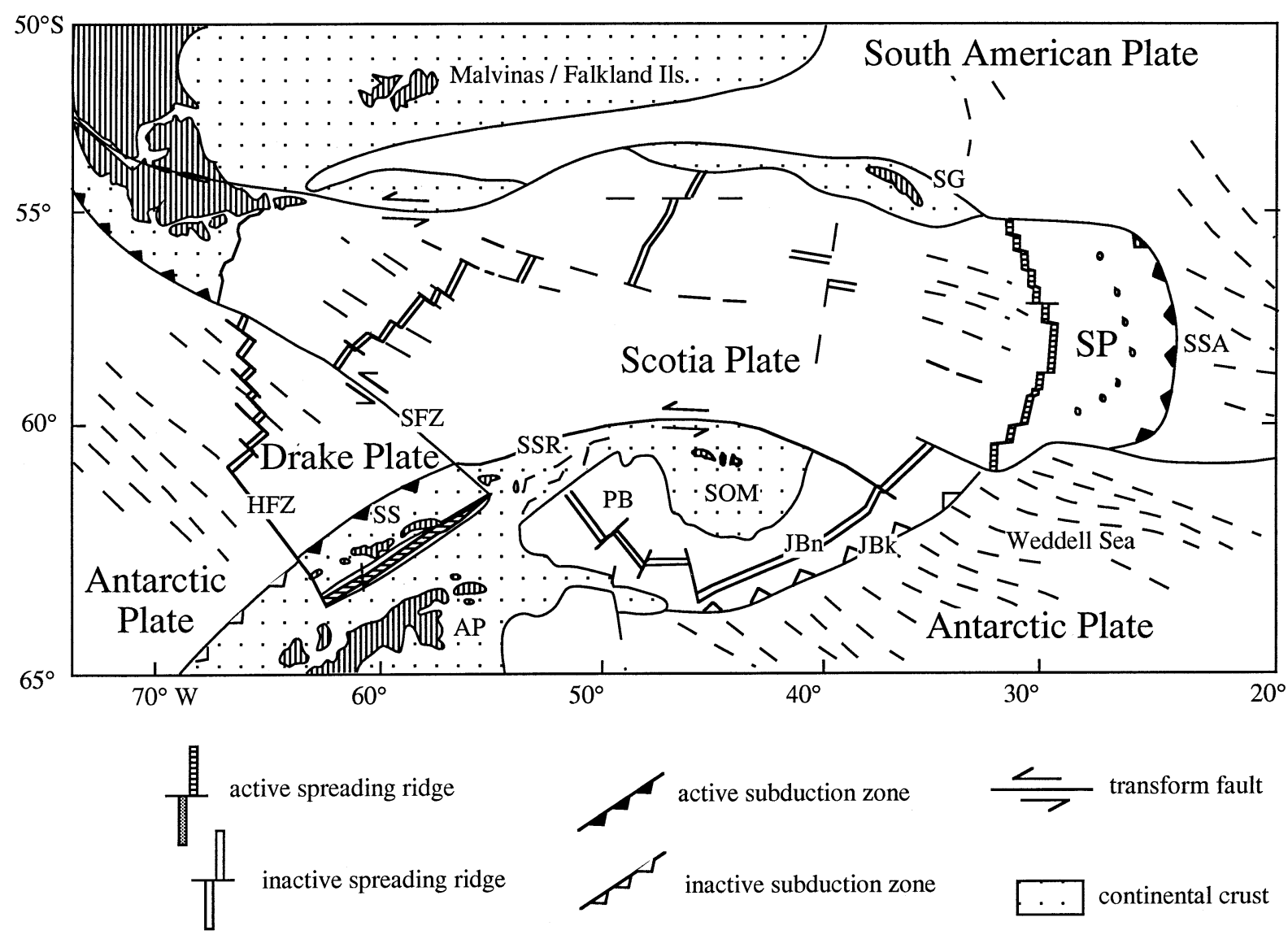

(b)

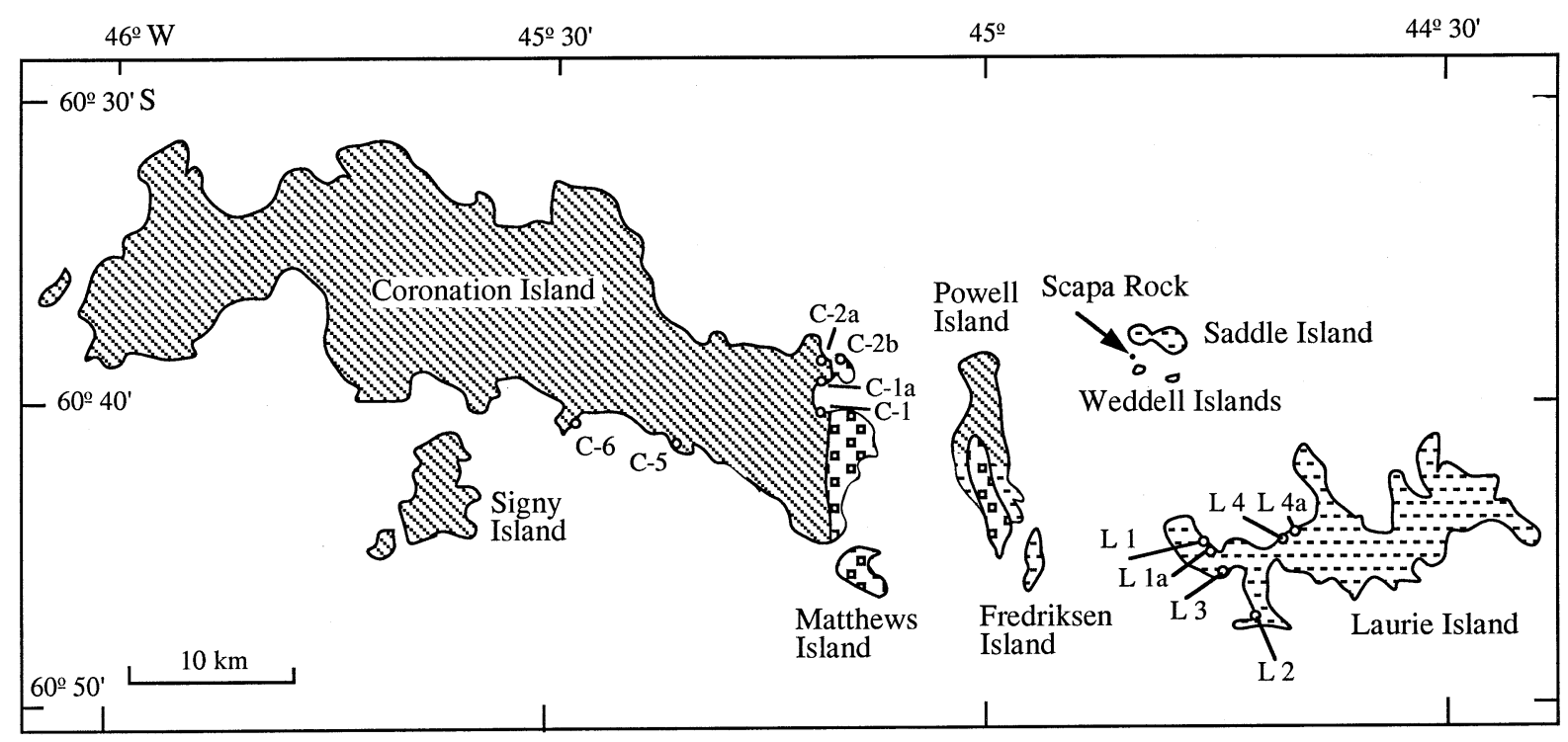

Figure 1. (a) Tectonic setting of the South Orkney Islands, modified after Galindo-Zaldivar et al. 1994. AP - Antarctic Peninsula; JBk Jane Bank; JBn - Jane Basin; HFZ - Hero fracture zone; PB - Powell Basin; SFZ - Shackleton fracture zone; SG - South Georgia; SOM - South Orkney Microcontinent; SP - Sandwich plate; SS - South Shetland Islands; SSA - South Sandwich arc; SSR - South Shetland ridge. (b) Geological map of the South Orkney Islands (after Thomson, 1973; Dalziel, 1984). Diagonal traces: metamorphic complex; horizontal dashes: Greywacke-Shale Formation; blocks: Spence Harbour and Powell Island conglomerates. Numbered points are visited stations. 


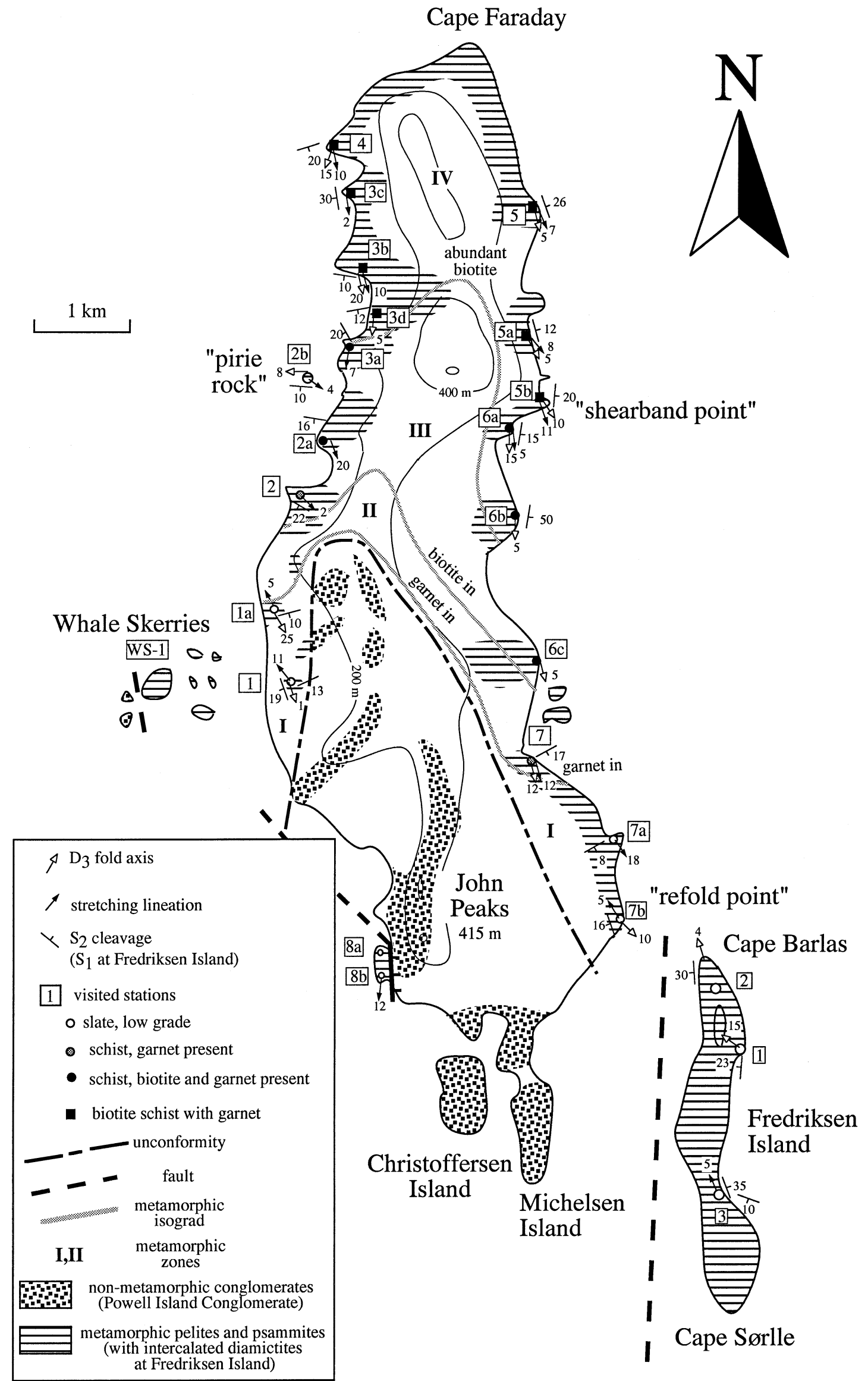

Figure 2. Geological map of Powell and surrounding islands showing visited stations and orientation of structures. Stations 1, 2 etc. at Powell Island are referred to in the text as PO-1, PO-2 etc. and at Fredriksen Island as FR-1, 2 etc. 
in beds of 1 to $50 \mathrm{~cm}$ thickness. Intense deformation has destroyed most original sedimentary structures, but correlation with nearby Fredriksen Island (where these structures are better preserved) suggests that these rocks belong to a marine turbidite sequence as discussed in Section 3.c. Further to the north, bedding is progressively transposed by metamorphic and deformational processes and the metasand- and siltstones change gradually into grey phyllites and schists. These, studied in thin section, reveal a surprisingly homogeneous composition that can be summarized as follows: quartz $25-50 \%$, albite $25-50 \%$, white mica $10-25 \%$, chlorite $1-15 \%$, epidote $0-10 \%$ and calcite $0-10 \%$. Common accessories are tourmaline, sphene and apatite. In addition, garnet and biotite appear (up to $5 \%$ each) in the northern part of Powell Island. At some places (e.g. station PO-5) varieties richer in calcite (up to $25 \%$ ) are also present. At stations PO-3A, PO-5A and PO-6C (Figs 2, 3) a greenschist occurs as intercalations of up to a few metres in thickness. This greenschist locally contains large (up to $1.5 \mathrm{~cm}$ ) garnet porphyroblasts and is further composed of the same minerals as the metasand- and siltstones, but in different proportions: albite $20-35 \%$, epidote $20-35 \%$, chlorite $15-25 \%$, garnet $1-10 \%$, calcite $2-6 \%$, sphene $2-10 \%$ and quartz $1-5 \%$. Traces of green amphibole and biotite are locally present. The greenschist may be derived from (i) intrusive or extrusive mafic igneous rocks, (ii) marls or (iii) sandstones composed predominantly of mafic lithic fragments. Since transitional compositions between greenschist and metasandstones have been found at some outcrops, the last two options are most likely.

\section{3.b. Whale Skerries}

This group of islands west of Powell Island (Fig. 2) is mainly composed of Greywacke-Shale Formation rocks (Thomson, 1973). We only visited the main island, which was found to be essentially constituted of highly fractured and faulted massive sandstones and conglomerates with clastic fragments of up to about one centimetre in diameter. Sedimentary structures are generally destroyed by intense deformation.

\section{3.c. Fredriksen Island}

The lowest grade part of the sequence of Powell and surrounding islands crops out at Fredriksen Island, probably separated from southern Powell Island by an approximately north-south trending fault (Fig. 2). The existence of this fault is deduced from the considerable contrast in structural style and in intensity of metamorphic recrystallization between stations PO-7B and FR-2 (Fig. 2). We studied three stations on the island (Figs 2, 3). At station FR-2 a well-bedded (meta)sedimentary succession is preserved, mainly composed of slates $(70 \%)$ and feldspathic metasandstones $(30 \%)$ with at least three intercalations of diamictites (up to $6 \mathrm{~m}$ thick, Fig. 4). The fragments in these diamictites vary from small pebbles (less than one centimetre in diameter) to blocks of over a metre in diameter; most pebbles are composed of sandstone but at least one is a (sub)volcanic rock, although weakly metamorphosed.

Storey \& Meneilly (1983) described a mélange at Fredriksen Island at a single visited station, "consisting of a chaotic arrangement of irregular sized blocks, up to $8 \mathrm{~m}$ across, of basic pillow lava, chert, felsite and epiclastic sandstone in a pervasively sheared cataclastic matrix". We visited this site as well (our station FR-1), but found that these blocks, studied in 22 thin sections, are mainly sandstone with some conglomeratic and few slightly metamorphosed lava pebbles. We interpret this outcrop as a deformed diamictite because we observed a planar contact in the northern part of this station with regular sandstone and pelite layers, similar to contacts observed along diamictites at station FR-2 (Fig. 4). At station FR-3 a similar, deformed diamictite crops out with pebbles and blocks of sandstone and slightly metamorphosed lava varying in size between a few centimetres and $10 \mathrm{~m}$.

Detailed study of the sedimentary structures in the well-stratified part (Fig. 4) shows that the (meta)sedimentary sequence of Fredriksen Island represents part of a submarine fan composed of interlayered pelite and sandstone that results from turbidity current processes. Intercalations of diamictite facies are the result of debris flows. The interpretation of the diamictites as sedimentary debris flow deposits intercalated within the turbidite succession is in accordance with descriptions of similar

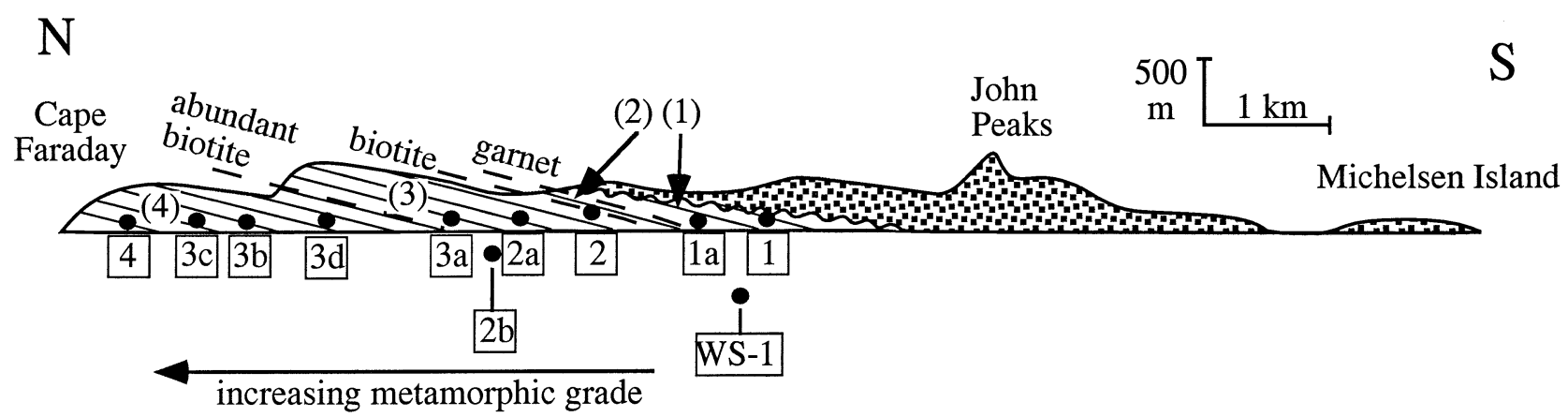

Figure 3. Geological section along the west coast of Powell Island; (1), (2), (3) and (4) refer to metamorphic zones (Fig. 2) explained in the text. 


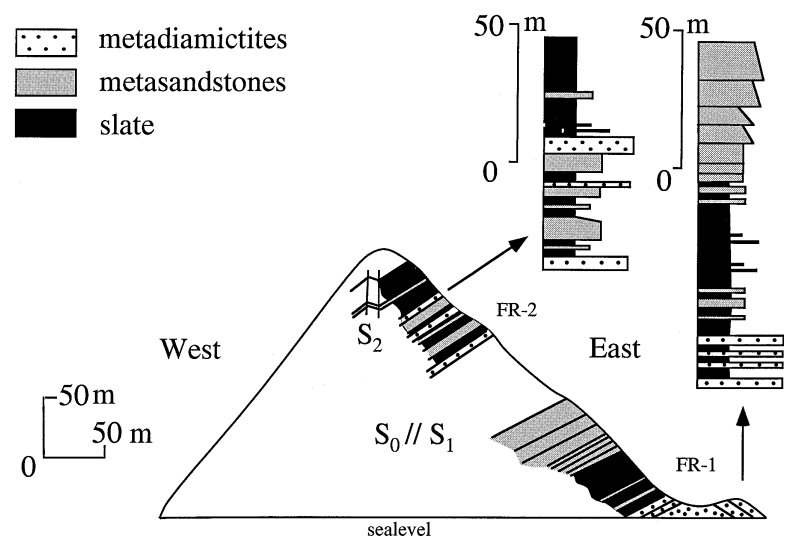

Figure 4. Geological section through Fredriksen Island with stratigraphic profiles elaborated at stations FR-1 and FR-2. Note the presence of meta-diamictite layers interstratified between metasandstone and slate.

occurrences in lithological units considered to be equivalent, such as the Trinity Peninsula Group at Cape Legoupil (Halpern, 1965; Ribeiro et al. 1994) and the Miers Bluff Formation at Livingston Island (Doktor, Swierczewska \& Tokarski, 1994).

Table 1. Whole rock chemical composition of five volcanic pebbles from the Greywacke-Shale Formation at Fredriksen Island

\begin{tabular}{|c|c|c|c|c|c|}
\hline & FR-1-8 & FR-1-10 & FR-2-12 & FR-3-1 & FR-3-2 \\
\hline $\mathrm{SiO}_{2}$ & 48.60 & 48.90 & 52.00 & 49.40 & 47.00 \\
\hline $\mathrm{TiO}_{2}$ & 1.90 & 0.66 & 2.40 & 2.10 & 2.30 \\
\hline $\mathrm{Al}_{2} \mathrm{O}_{3}$ & 13.90 & 15.80 & 15.40 & 15.20 & 16.60 \\
\hline $\mathrm{Fe}_{2} \mathrm{O}_{3}$ & 1.60 & 8.00 & 5.40 & 2.00 & 2.70 \\
\hline $\mathrm{FeO}$ & 4.60 & 3.50 & 3.80 & 6.30 & 6.40 \\
\hline $\mathrm{MnO}$ & 0.13 & 0.16 & 0.21 & 0.13 & 0.13 \\
\hline $\mathrm{MgO}$ & 2.20 & 3.10 & 3.50 & 5.30 & 5.90 \\
\hline $\mathrm{CaO}$ & 11.20 & 6.70 & 5.50 & 6.40 & 5.70 \\
\hline $\mathrm{Na}_{2} \mathrm{O}$ & 6.00 & 5.40 & 5.50 & 5.30 & 5.40 \\
\hline $\mathrm{K}_{2} \mathrm{O}$ & 0.17 & 0.13 & 0.10 & 0.09 & 0.35 \\
\hline $\mathrm{P}_{2} \mathrm{O}_{5}$ & 0.41 & 0.20 & 0.32 & 0.38 & 0.39 \\
\hline Total & 90.71 & 92.55 & 94.13 & 92.60 & 92.87 \\
\hline \multicolumn{6}{|c|}{ Trace elements (ppm) } \\
\hline $\mathrm{Cr}$ & 68 & 890 & 68 & 233 & 226 \\
\hline $\mathrm{Ni}$ & - & - & - & 110 & 110 \\
\hline $\mathrm{Rb}$ & 11 & 10 & 8 & 12 & 20 \\
\hline $\mathrm{Sr}$ & 270 & 240 & 350 & 340 & 528 \\
\hline Y & 64 & 30 & 33 & 17 & 24 \\
\hline $\mathrm{Zr}$ & 190 & 41 & 230 & 204 & 222 \\
\hline $\mathrm{Nb}$ & 23.0 & - & 30.0 & 22.0 & 28.0 \\
\hline $\mathrm{Ba}$ & 985 & 116 & 90 & 96 & 130 \\
\hline Co & 36 & 45 & 48 & - & - \\
\hline V & 169 & 281 & 225 & - & - \\
\hline \multicolumn{6}{|c|}{ Rare Earth Elements } \\
\hline $\mathrm{La}$ & 13.67 & 4.52 & 9.41 & 23.50 & 24.30 \\
\hline $\mathrm{Ce}$ & 31.91 & 13.69 & 26.45 & 54.68 & 56.85 \\
\hline $\mathrm{Nd}$ & 24.94 & 8.53 & 20.68 & 29.11 & 31.12 \\
\hline $\mathrm{Sm}$ & 7.45 & 2.23 & 4.99 & 5.76 & 5.82 \\
\hline $\mathrm{Eu}$ & 2.39 & 0.53 & 1.89 & 1.67 & 1.71 \\
\hline $\mathrm{Gd}$ & 7.24 & 2.17 & 4.23 & 4.67 & 4.86 \\
\hline Dy & 6.43 & 1.99 & 3.53 & 3.61 & 4.20 \\
\hline Ho & 1.35 & 0.45 & 0.73 & 0.65 & 0.76 \\
\hline $\mathrm{Er}$ & 3.38 & 1.52 & 2.17 & 1.39 & 1.67 \\
\hline $\mathrm{Yb}$ & 2.11 & 1.12 & 1.69 & 0.75 & 0.99 \\
\hline $\mathrm{Lu}$ & 0.25 & 0.15 & 0.22 & 0.10 & 0.10 \\
\hline
\end{tabular}

For location of stations FR-1 to FR-3, see Figure 2.
The chemical compositions of the volcanic rock pebbles (Table 1) plot in the field of basaltic trachyandesites in the classification diagram of le Maitre (1989) (Fig. 5a) and show considerable differentiation in a chondrite normalized spidergram (Fig. 5b). The tendency of these rocks is alkaline rather than calc-alkaline and they do not define a clear tectonic environment. The analyses are somewhat different from analyses of mafic rocks from Signy Island (Fig. 1b) (Storey \& Meneilly, 1985) that fall mainly in the basalt field in the classification diagram of le Maitre (1989). Storey \& Meneilly (1985) interpreted the rocks from Signy Island as representing enriched tholeiitic and alkali basalts of an oceanic intraplate basalt series. In our understanding the composition of the pebbles is not conclusive and they may equally well be derived from a continental margin.

\section{Provenance of metasandstones}

Metasandstones from southern Powell Island (stations PO-8, PO-8A, PO-1), the Whale Skerries and Fredriksen Island (Fig. 2) can be classified as medium clean plagioclase arenites and less abundant wackes. Two populations were identified: (i) relatively quartz-rich arenites and (ii) arenites rich in plagioclase and lithic volcanic fragments. Detrital fragments have the following composition: quartz (monocrystalline > polycrystalline), feldspar (albite-oligoclase > orthoclase + microcline) and minor lithic components. In order of abundance the lithic components consist of: (i) clasts of volcanic/pyroclastic origin (including several types of andesites, vitric tuffs and andesitic ignimbrites); (ii) clasts of plutonic origin (tonalite, granodiorite > granite, monzonite); (iii) clasts of metamorphic rocks (phyllites, mica-schists, and less granite gneiss and mylonite); and (iv) clasts of sedimentary rocks (fine feldspathic arenites, siltstones and claystones). Most of these sedimentary rock fragments are restricted to coarse arenites and fine diamictites. Other clastic fragments in these arenites are: recrystallized volcanic glass (pecilite), lithic breccias (with abundant angular fragments of andesite), brown and partially chloritized biotite, chlorite, muscovite and accessory epidote, allanite, zircon and apatite. The less-deformed sandstones retain most of their sedimentary characteristics, such as clast outlines, that show mainly subangular to minor angular shapes. Circularity shows medium to high values $(0.62-0.82)$. The contacts between clasts are mainly of the tangential and planar types, with less frequent concave-convex and sutured types; the latter become more frequent in more strongly deformed sandstones. In a few samples faint syntaxial growth of quartz (on quartz grains) and of albite on oligoclase grains was detected.

In the wackes ortho-matrix appears as recrystallized aggregates of white mica without preferred orientation. In the arenites, these aggregates appear as thin envelopes that partly or completely surround clasts. Reaction between these envelopes and clasts produces disappearance 

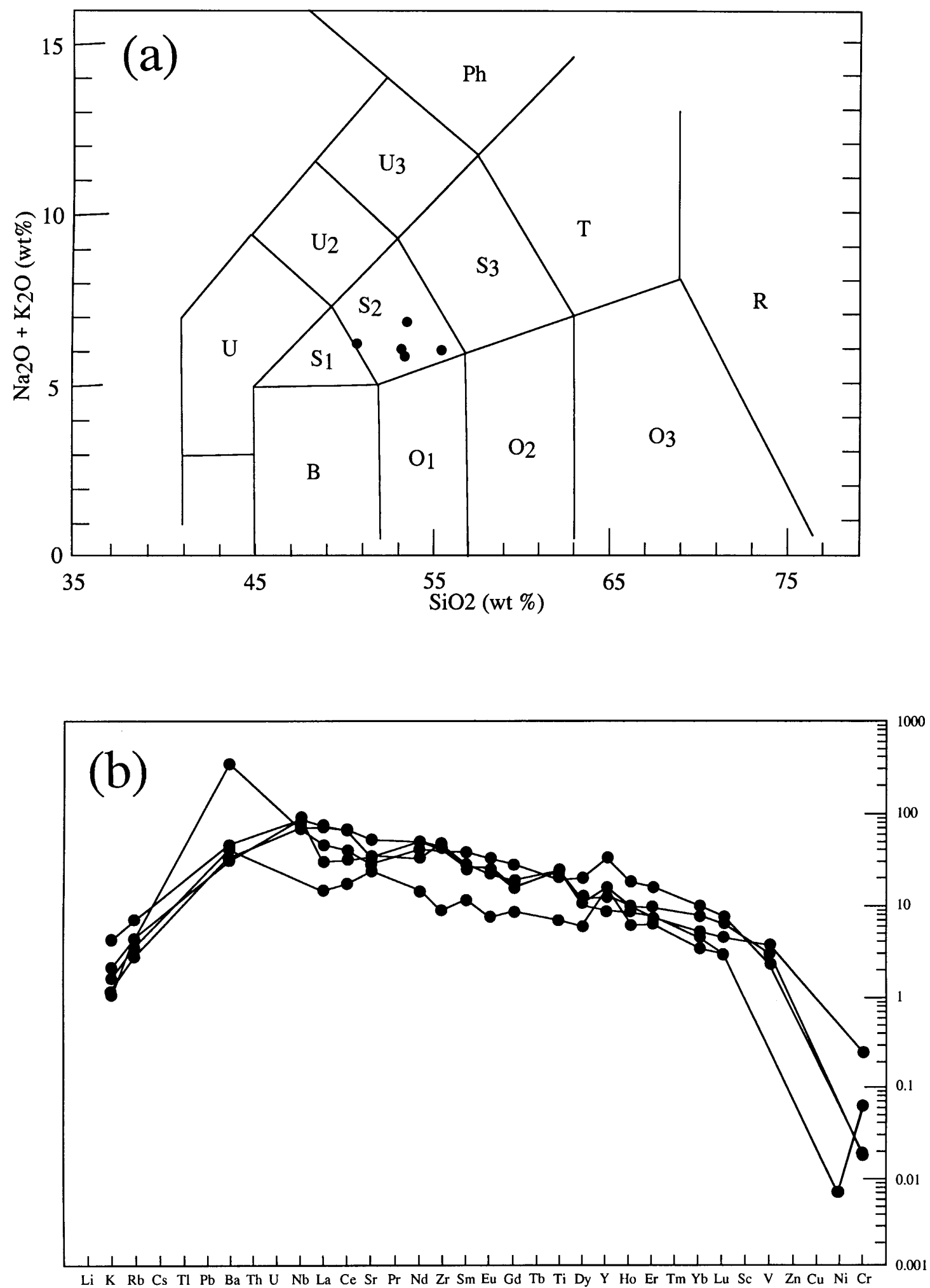

Figure 5. (a) Five analyses of volcanic lava pebbles from Fredriksen Island plotted in the compositional diagram of le Maitre (1989). B - basalt; $\mathrm{O}_{1}$ - basaltic andesite; $\mathrm{O}_{2}$ - andesite; $\mathrm{O}_{3}$ - dacite; $\mathrm{Ph}$ - phonolite; $\mathrm{R}$ - rhyolite; $\mathrm{S}_{1}$ - trachybasalt; $\mathrm{S}_{2}$ - basaltic trachyandesite; $\mathrm{S}_{3}$ - trachyandesite; $\mathrm{T}$ - trachyte and trachydacite; $\mathrm{U}$ - tefrite and basanite; $\mathrm{U}_{2}-$ phonotephrite; $\mathrm{U}_{3}-$ tephriphonolite. All analyses fall in field $S_{2}$ of basaltic trachyandesites. (b) Spidergram normalized to chondrite, showing considerable differentiation for the five analysed volcanic pebbles from Fredriksen Island. 
of clastic borders. Except for the claystone intraclasts (pseudo-matrix), all other components are extrabasinal in origin.

The composition of the arenites is given in Table 2. In the Qt-F-L diagram (where L includes volcanic, sedimentary and metasedimentary fragments), given by Dickinson (1985) for tectonic classification of provenance (Fig. 6a), the samples plot mainly in the 'recycled orogen' field, and few in the 'dissected arc' field. In the Qm-F-Lt diagram (Dickinson, 1985) the sixteen samples are distributed in various fields (Fig. 6b): 'dissected arc' (5), 'quartzose recycled orogen' (5), 'mixed' (5) and 'transitional continental' (1). Valloni (1985) presented a Lq-Lv-Ls diagram to clarify provenance for cases where the Qm-F-Lt diagram of Dickinson (1985) is not conclusive (Fig. 6c). In this diagram the samples plot mainly in two overlapping fields: 'plate-juncture orogenic highland provenance' (10) and 'continental-arc provenance' (8). Together, the three diagrams are interpreted to indicate provenance from a dissected continental magmatic arc and its basement, partially covered by an epiclastic sedimentary succession. The calculated values of $\mathrm{Qp} / \mathrm{Q}, \mathrm{P} / \mathrm{F}$ and V/L ratios (Valloni, 1985) corroborate this interpretation. Smellie (1991) and Andreis, Ribeiro \& Trouw (1997) came to a similar conclusion for the Trinity Peninsula Group, Greywacke-Shale Formation and Miers Bluff Formation, and Doktor, Swierczewska \& Tokarski (1994) for the Miers Bluff Formation.

\section{Metamorphism}

Thomson (1973) has given some detailed descriptions of thin sections and also modal analyses from Powell Island, and Dalziel (1984) described the structural, metamorphic and lithological transition between the metamorphic northern part and the non-metamorphic (or much less metamorphic) southern part. However, no detailed description of metamorphism on the island has yet been published. The description given below is based on thin section study and illite crystallinity data.
The lowest grade rocks, at Laurie and Fredriksen islands, show perfectly recognizable detrital grains of quartz, plagioclase, epidote, white mica and biotite. The only visible effect of the metamorphism is the partial decalcification of plagioclase to albite, the incomplete chloritization of clastic biotite, the appearance of tiny metamorphic white mica grains in the matrix and the local occurrence of prehnite, especially in veins and in metavolcanic rocks. In lavas (or subvolcanic rocks), igneous textures are partially preserved, plagioclase grains are albitized and pyroxene (or amphibole) is almost completely substituted by calcite, chlorite and prehnite. The latter generally forms radiate sheaf-like aggregates.

Two metamorphic isograds, marking the appearance of garnet and biotite, were established on Powell Island (Figs 2, 3). The garnet isograd is sharply defined by the sudden appearance of well-developed garnet grains (almandine) in rocks of uniform composition. However, the biotite isograd constitutes a wide zone on the map, covering the range from the first appearance of a few tiny crystals to the general appearance of biotite as a rock forming mineral (marked on the map as 'abundant' biotite). In addition to these isograds, the change in metamorphic grade at Powell Island is also apparent from the gradual increase in both grainsize and quantity of metamorphic white mica. The island can be subdivided by the isograds into four metamorphic zones (Figs 2, 3): zone I without garnet or biotite, comparable to Laurie and Fredriksen islands and also to the Whale Skerries; zone II with garnet but without biotite; zone III with garnet and locally small biotite $(<1 \%)$; and zone IV with garnet and relatively abundant biotite (about $5 \%$ ).

In zone I, recognizable metamorphic minerals are albite, quartz, chlorite, epidote, white mica, calcite and sphene. In most thin sections, all these minerals occur together, showing that they constitute a stable association. In one thin section from station PO-8, pumpellyite was recognized, in a vein in a metasiltstone. Within zone I a gradual transition takes place from 'sedimentary looking'

Table 2. Total composition of metasandstones from Fredriksen Island, southern Powell Island, the Whale Skerries and Laurie Island (Fig. 2)

\begin{tabular}{|c|c|c|c|c|c|c|c|c|c|c|c|c|c|c|c|c|c|c|c|c|c|c|c|c|c|}
\hline & \multirow{2}{*}{\multicolumn{10}{|c|}{ Fredriksen Island }} & \multirow{2}{*}{\multicolumn{3}{|c|}{ Powell Island }} & \multirow{2}{*}{\multicolumn{3}{|c|}{ Whale Skerries }} & \multirow{2}{*}{\multicolumn{9}{|c|}{ Laurie Island }} \\
\hline & & & & & & & & & & & & & & & & & & & & & & & & & \\
\hline & $\begin{array}{l}\text { FR } \\
1-4\end{array}$ & $\begin{array}{r}\text { FR } \\
1-17\end{array}$ & $\begin{array}{c}\text { FR } \\
1-22\end{array}$ & $\begin{array}{l}\text { FR } \\
2-2\end{array}$ & $\begin{array}{l}\text { FR } \\
2-5\end{array}$ & $\begin{array}{l}\text { FR } \\
2-7\end{array}$ & $\begin{array}{l}\text { FR } \\
2-8\end{array}$ & $\begin{array}{c}\text { FR } \\
2-11\end{array}$ & $\begin{array}{l}\text { FR } \\
3-4\end{array}$ & $\begin{array}{l}\text { FR } \\
3-5\end{array}$ & $\begin{array}{l}\mathrm{PO} \\
8 \mathrm{~A}- \\
1 \mathrm{~A}\end{array}$ & $\begin{array}{c}\mathrm{PO} \\
8 \mathrm{~A}- \\
1 \mathrm{~B}\end{array}$ & $\begin{array}{l}\text { PO } \\
8-1\end{array}$ & $\begin{array}{l}\text { WS } \\
1-3\end{array}$ & \multicolumn{2}{|c|}{$\begin{array}{ll}\text { WS } & \text { WS } \\
1-13 & 1-17\end{array}$} & $\begin{array}{c}\mathrm{L} \\
2-3\end{array}$ & $\begin{array}{c}\mathrm{L} \\
2-9 \mathrm{~A}\end{array}$ & $\begin{array}{c}\mathrm{L} \\
2-8\end{array}$ & $\begin{array}{c}\mathrm{L} \\
2-1\end{array}$ & $\begin{array}{c}\mathrm{L} \\
2-4^{*}\end{array}$ & $\begin{array}{c}\mathrm{L} \\
3-3\end{array}$ & $\begin{array}{c}\mathrm{L} \\
3-8\end{array}$ & $\begin{array}{c}\mathrm{L} \\
2-11\end{array}$ & $\begin{array}{c}\mathrm{L} \\
1 \mathrm{a}-1\end{array}$ \\
\hline Qm & 36 & 44 & 39 & 37 & 65 & 38 & 39 & 26 & 54 & 59 & 43 & 41 & 40 & 34 & 23 & 3 & 40 & 34 & 39 & 42 & 27 & 44 & 40 & 36 & 28 \\
\hline $\mathrm{Qp}$ & 6 & 5 & 7 & 7 & 7 & 6 & 6 & 6 & 8 & 6 & 6 & 5 & 13 & 11 & 11 & 10 & 7 & 4 & 3 & 2 & 11 & 8 & 5 & 3 & 5 \\
\hline Or & 4 & 5 & 4 & 8 & 4 & 4 & 3 & 6 & 2 & 3 & 1 & 1 & 1 & 1 & - & - & 7 & 8 & 8 & 9 & 5 & 10 & 12 & 13 & 3 \\
\hline $\mathrm{Mc}$ & - & 1 & 1 & 1 & 1 & 2 & 1 & - & 1 & 1 & - & - & - & - & - & - & 2 & 2 & 2 & 1 & - & 2 & 3 & 4 & - \\
\hline $\mathrm{P}$ & 22 & 17 & 24 & 29 & 14 & 25 & 21 & 31 & 15 & 15 & 15 & 13 & 9 & 19 & 6 & 10 & 15 & 14 & 30 & 20 & 6 & 21 & 27 & 32 & 12 \\
\hline $\mathrm{Lv}$ & 9 & 8 & 9 & 6 & 6 & 8 & 8 & 11 & 5 & 5 & 20 & 18 & 10 & 5 & 2 & 2 & 16 & 12 & 9 & 14 & 25 & 6 & 6 & 7 & 23 \\
\hline Ls & - & - & - & - & - & - & - & - & 2 & 2 & 2 & 4 & 7 & 4 & 2 & 5 & 3 & - & - & - & 17 & - & 1 & - & 18 \\
\hline $\mathrm{Lm}$ & 3 & 3 & 7 & 4 & 1 & 4 & 3 & 8 & 2 & 2 & 4 & 2 & 3 & 6 & 19 & 8 & 3 & 3 & 5 & 2 & 6 & 1 & 3 & 2 & 10 \\
\hline Micas & 1 & 1 & 7 & 6 & - & 9 & 14 & 8 & 3 & 4 & 1 & 1 & 1 & - & - & - & 4 & 16 & 5 & 9 & - & 1 & - & 4 & - \\
\hline Ortmtx & 19 & 12 & 2 & 2 & 1 & 2 & 4 & 4 & 8 & 3 & 7 & 15 & 16 & 20 & 35 & 29 & 3 & 7 & - & - & - & 7 & 2 & 2 & 1 \\
\hline Pseudm & - & 4 & - & - & 1 & 1 & 1 & - & - & - & - & - & - & - & - & - & - & - & - & 2 & - & - & - & - & - \\
\hline
\end{tabular}

Abbreviations as defined in Dickinson (1985).

* Conglomerate. 

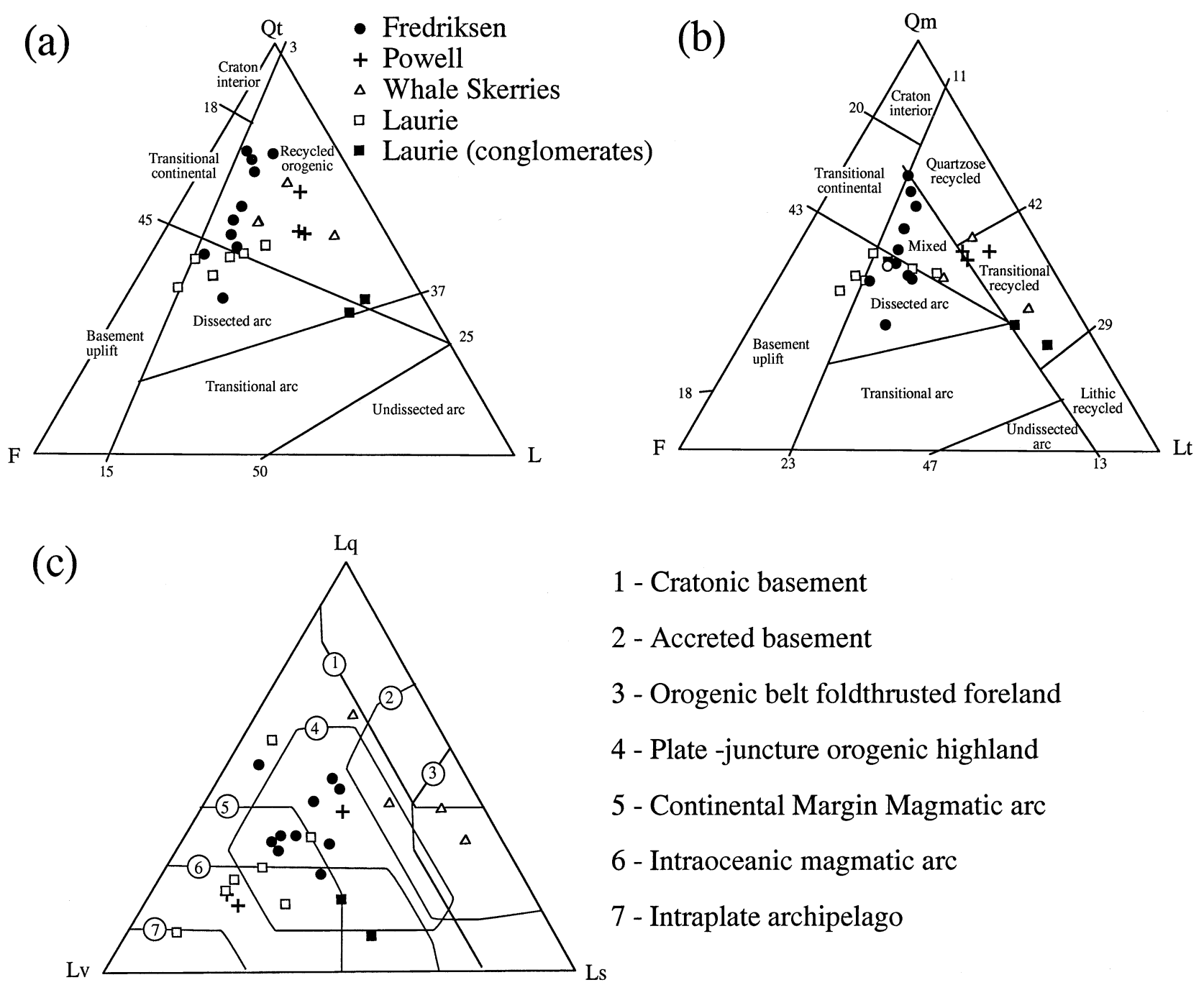

\section{1 - Cratonic basement}

\section{2 - Accreted basement}

\section{3 - Orogenic belt foldthrusted foreland}

\section{4 - Plate -juncture orogenic highland}

\section{5 - Continental Margin Magmatic arc}

\section{6 - Intraoceanic magmatic arc}

\section{7 - Intraplate archipelago}

Figure 6. (a) Qt-F-L diagram proposed by Dickinson (1985) to distinguish provenance of arenites, with data of meta-arenites from the South Orkney Islands. (b) Qm-F-Lt diagram proposed by Dickinson (1985) to define the tectonic environment of the source-area of arenites. (c) Lq-Lv-Ls diagram proposed by Valloni (1985) to clarify provenance for cases where the Qm-F-Lt diagram of Dickinson is not conclusive. Lq - quartzose lithics, Lv - volcanic-metavolcanic lithics, Ls - sedimentary-metasedimentary lithics. Further explanation in text.

rocks with recognizable bedding and clast-matrix relationships preserved, to 'metamorphic looking' rocks in which secondary foliation and recrystallization predominate over original features. Illite crystallinity data on the islands are published in Trouw, Pankhurst \& Ribeiro (1997), including Kubler index values measured on $<2 \mu \mathrm{m}$ white mica fractions and $b_{0}$ values measured on rock slabs. The Kubler index values are indicative for temperature (Kisch, 1990) and the $b_{0}$ values correspond in a broad sense to pressure (Guidotti \& Sassi, 1986). They are tentatively plotted on a $P T$ diagram (Fig. 7), together with data from the surrounding islands. Although there is some scatter in $b_{0}$ values, the data are consistent with a gradual increase in metamorphic grade in the following sequence: Laurie and Fredriksen islands - Whale Skerries - zone I of southern Powell Island. Also, a gradual increase in temperature within zone I and between the Greywacke-Shale Formation and the 'metamorphic complex' is apparent (Fig. 7).
In zone II the mineralogy of zone I remains stable. The only difference with zone I is that in some thin sections, garnet appears as an additional mineral. In fact there is only one station (PO-7) in this narrow zone.

In zone III the mineral association mentioned for zones I and II remains stable, with the addition of sparce biotite in about half of the examined thin sections. At one station within this zone (PO-6C) stilpnomelane is present as an accessory mineral, commonly associated with calcite. Zone IV is characterized by the presence of biotite as a rock forming mineral in most studied thin sections.

In terms of metamorphic facies the rocks of Powell Island fit in the greenschist facies with a possible gradation in the south to sub-greenschist facies, whereas those from Fredriksen Island can be grouped in the prehnite (pumpellyite) facies. The $P-T$ conditions can be estimated as shown in Figure 7, based on a petrogenetic grid (Yardley, 1989; Barker, 1991). Although no typical high pressure minerals have been detected on the island, the 


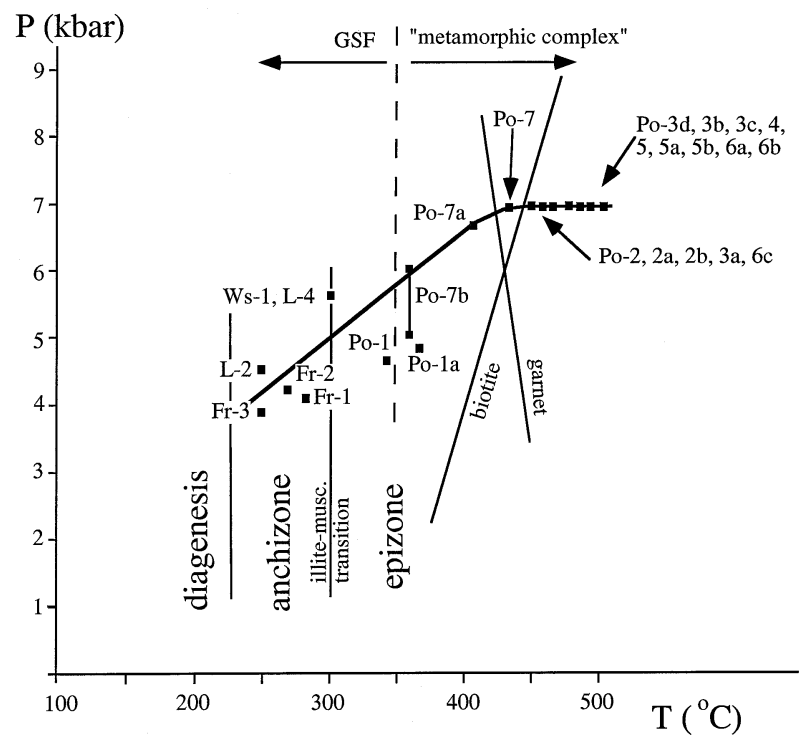

Figure 7. Array of probable peak $P-T$ conditions for analysed samples from Powell and surrounding islands; they are based on illite crystallinity data for samples at the lower grade side of the garnet isograd, on Si content in white mica measured by microprobe and $a b_{o}$ parameters (see text), and on the appearance of garnet before biotite in pelitic assemblages with increasing grade. Stability field of almandine based on Yardley (1989, his fig. 3-11); estimated reaction curve for first appearance of biotite after Nitsch (1970). Note the gradual transition between the Greywacke-Shale Formation (GSF) and 'metamorphic complex' samples.

pressure must nevertheless have been relatively high because of the inversion of the biotite and garnet isograds as compared to standard Barrovian sequences (see, e.g. Yardley, 1989). A similar inversion occurs in the classical Sanbagawa Belt in Japan (Banno, 1986) and has been reported from another part of the Scotia metamorphic complex, at Elephant Island in the South Shetland Islands (Trouw, Ribeiro \& Paciullo, 1991). Another indication for moderate to high pressure is the relatively high silica content in white mica from station PO-7B. Eleven microprobe analyses (Table 3) show an Si content per formula unit between 3.31 and 3.39. According to the calibration presented by Massone \& Schreyer (1987), later modified by Massone (H. J. Massone, unpub. thesis, Ruhr Univ., Bochum, Germany, 1991), and assuming a metamorphic peak temperature for this zone of about $360^{\circ} \mathrm{C}$, based on the illite crystallinity data discussed above, the pressure would have been between 5 and 6 kbar (Fig. 7).

\section{Structures}

The main reference structure on Powell Island is a welldeveloped flat-lying foliation in the Greywacke-Shale Formation, characterized by the approximate parallelism of micas and other platy or acicular minerals, quartz-rich lenses and veins, and lenticular mineral aggregates. In many thin sections, remnants of tight crenulations of an older tectonic foliation can be recognized along the foliation planes. For this reason the main foliation has been labelled $\mathrm{S}_{2}$, ascribed to a second deformation phase. The orientation of $\mathrm{S}_{2}$, predominantly dipping weakly to the south, is shown in Figure 8a. A conspicuous stretching lineation, $\mathrm{L}_{2}$, with a regular NNW-SSE orientation (Fig. 8b) is usually associated with $\mathrm{S}_{2}$.

In many outcrops $S_{2}$ is folded on a centimetric to metric scale by tight to open folds in which generally no new axial planar cleavage is developed. These folds have been labelled $\mathrm{D}_{3}$. They have axial surfaces that dip moderately to the southwest and axes that plunge

Table 3. Composition of eleven white mica crystals in a sample of grey slate from station PO-7b (Fig. 2)

\begin{tabular}{|c|c|c|c|c|c|c|c|c|c|c|c|}
\hline & 1 & 2 & 3 & 4 & 5 & 6 & 7 & 8 & 9 & 10 & 11 \\
\hline $\mathrm{SiO}_{2}$ & 49.10 & 49.31 & 48.18 & 48.65 & 50.17 & 48.35 & 49.91 & 48.61 & 50.10 & 49.70 & 48.63 \\
\hline $\mathrm{TiO}_{2}$ & 0.12 & 0.13 & 0.15 & 0.13 & 0.07 & 0.17 & 0.10 & 0.13 & 0.10 & 0.00 & 0.12 \\
\hline $\mathrm{Al}_{2} \mathrm{O}_{3}$ & 26.93 & 28.44 & 27.15 & 27.32 & 27.74 & 27.34 & 27.15 & 27.40 & 27.76 & 29.82 & 27.95 \\
\hline $\mathrm{Cr}_{2}^{2} \mathrm{O}_{3}^{3}$ & 0.00 & 0.00 & 0.00 & 0.00 & 0.00 & 0.18 & 0.00 & 0.00 & 0.00 & 0.15 & 0.00 \\
\hline $\mathrm{CaO}^{3}$ & 0.00 & 0.00 & 0.00 & 0.00 & 0.00 & 0.00 & 0.00 & 0.00 & 0.00 & 0.00 & 0.00 \\
\hline $\mathrm{MgO}$ & 2.87 & 2.67 & 2.77 & 3.00 & 3.13 & 3.33 & 2.54 & 2.89 & 2.62 & 2.24 & 2.62 \\
\hline $\mathrm{FeO}$ & 3.60 & 4.08 & 4.49 & 4.90 & 4.23 & 5.20 & 3.85 & 4.40 & 3.16 & 2.93 & 3.69 \\
\hline $\mathrm{MnO}$ & 0.00 & 0.00 & 0.00 & 0.06 & 0.03 & 0.00 & 0.05 & 0.03 & 0.00 & 0.00 & 0.00 \\
\hline $\mathrm{ZnO}$ & 0.00 & 0.34 & 0.00 & 0.00 & 0.37 & 0.66 & 0.00 & 0.00 & 0.35 & 0.00 & 0.00 \\
\hline $\mathrm{Na}_{2} \mathrm{O}$ & 0.08 & 0.09 & 0.11 & 0.09 & 0.08 & 0.12 & 0.12 & 0.12 & 0.12 & 0.18 & 0.08 \\
\hline $\mathrm{K}_{2} \mathrm{O}$ & 10.13 & 10.26 & 10.14 & 9.88 & 9.84 & 10.41 & 10.76 & 10.30 & 10.19 & 10.40 & 10.14 \\
\hline Total & 92.83 & 95.32 & 92.99 & 94.03 & 95.66 & 95.76 & 94.48 & 93.88 & 94.40 & 95.42 & 93.23 \\
\hline $\mathrm{Si}$ & 6.74 & 6.62 & 6.66 & 6.66 & 6.71 & 6.56 & 6.78 & 6.66 & 6.77 & 6.63 & 6.66 \\
\hline $\mathrm{Ti}$ & 0.01 & 0.01 & 0.02 & 0.01 & 0.01 & 0.02 & 0.01 & 0.01 & 0.01 & 0.00 & 0.01 \\
\hline $\mathrm{Al}$ & 4.36 & 4.50 & 4.43 & 4.41 & 4.37 & 4.37 & 4.34 & 4.43 & 4.42 & 4.69 & 4.51 \\
\hline $\mathrm{Cr}$ & 0.00 & 0.00 & 0.00 & 0.00 & 0.00 & 0.02 & 0.00 & 0.00 & 0.00 & 0.02 & 0.00 \\
\hline $\mathrm{Ca}$ & 0.00 & 0.00 & 0.00 & 0.00 & 0.00 & 0.00 & 0.00 & 0.00 & 0.00 & 0.00 & 0.00 \\
\hline $\mathrm{Mg}$ & 0.59 & 0.53 & 0.57 & 0.61 & 0.63 & 0.68 & 0.51 & 0.59 & 0.53 & 0.45 & 0.54 \\
\hline $\mathrm{Fe}$ & 0.41 & 0.46 & 0.52 & 0.56 & 0.47 & 0.59 & 0.44 & 0.50 & 0.38 & 0.33 & 0.42 \\
\hline $\mathrm{Mn}$ & 0.00 & 0.00 & 0.00 & 0.01 & 0.00 & 0.00 & 0.01 & 0.00 & 0.00 & 0.00 & 0.00 \\
\hline $\mathrm{Zn}$ & 0.00 & 0.03 & 0.00 & 0.00 & 0.04 & 0.07 & 0.00 & 0.00 & 0.03 & 0.00 & 0.00 \\
\hline $\mathrm{Na}$ & 0.02 & 0.02 & 0.03 & 0.02 & 0.02 & 0.03 & 0.03 & 0.03 & 0.03 & 0.05 & 0.02 \\
\hline $\mathrm{K}$ & 1.78 & 1.76 & 1.80 & 1.73 & 1.67 & 1.81 & 1.86 & 1.80 & 1.75 & 1.76 & 1.78 \\
\hline
\end{tabular}

Composition per formula unit is calculated on the basis $\mathrm{O}=22$. 

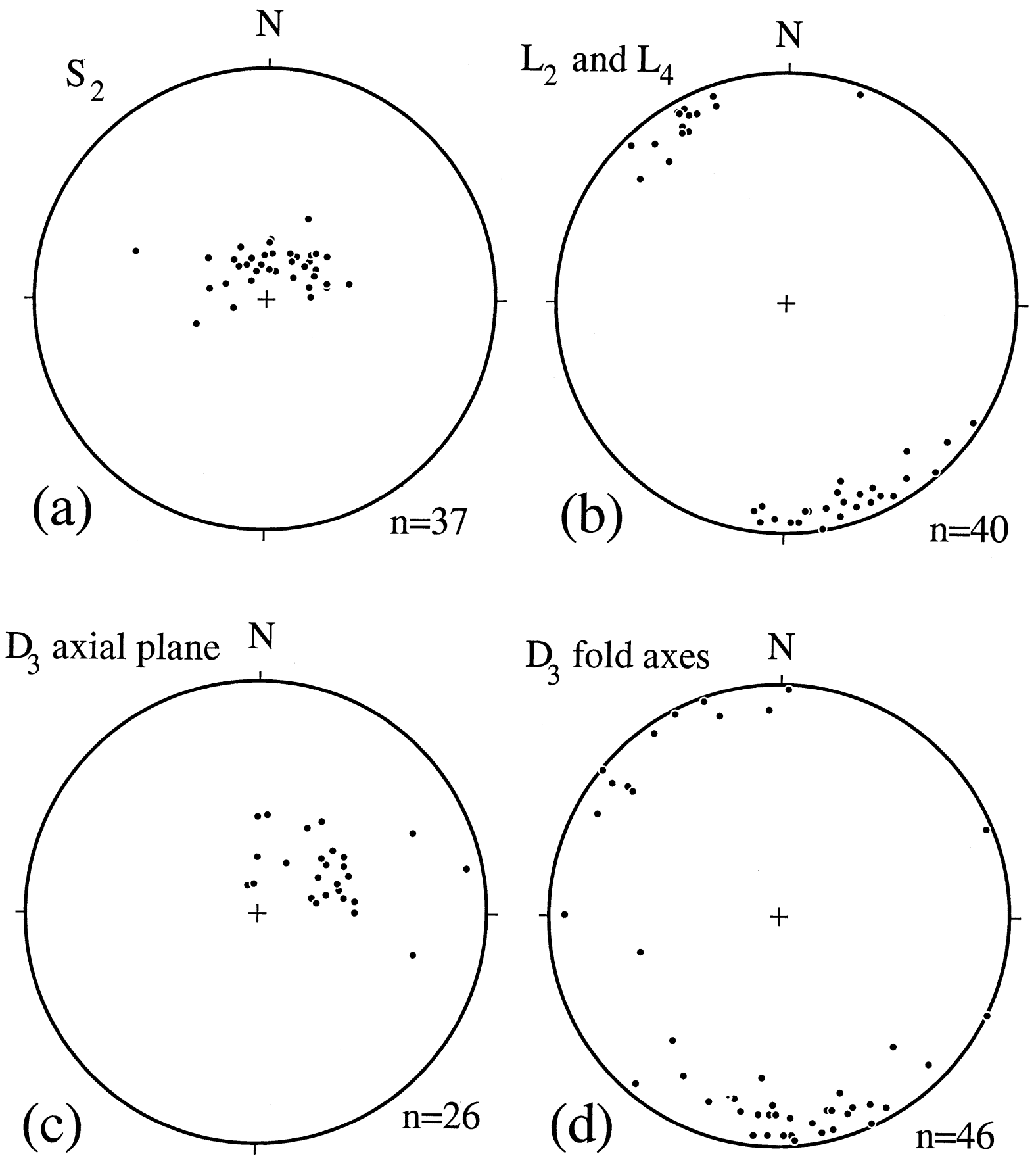

Figure 8. Equal area stereoplots of structures on Powell Island: (a) Poles to $\mathrm{S}_{2}$ planes; (b) $\mathrm{L}_{2}$ and $\mathrm{L}_{4}$ lineations (see text for explanation); (c) poles to axial planes of $\mathrm{D}_{3}$ folds; (d) $\mathrm{D}_{3}$ fold axes.

predominantly to the south-southeast (Fig. 8c, d). Many $\mathrm{D}_{3}$ folds are asymmetric with a vergence to the east.

A conspicuous feature at most outcrops is the presence of shear bands, either developed along the $\mathrm{S}_{2}$ foliation or, more often, making a small angle with $\mathrm{S}_{2}$ (Fig. 9). The shear bands are mostly of C'-type (Passchier \& Trouw, 1996), but C-type shear bands do also occur. In outcrop and in thin section (Fig. 9), these shear bands define a dominant 'top to the south' sense of shear; of 20 oriented thin sections 17 gave this result, two gave the opposite result and one gave shear in both senses. The presence of conflicting shear sense markers may indicate that non-coaxial flow locally deviated from simple shear, for example as a 'stretching shear zone' (Means, 1989; Passchier, 1991).

The shear bands indicate a down-dip normal movement, attributed to $\mathrm{D}_{4}$. The stretching lineations associated with this phase $\left(\mathrm{L}_{4}\right)$, interpreted to reflect the main movement direction, are subparallel to $\mathrm{L}_{2}$ lineations (Fig. 8b). In the field they are virtually indistinguishable but in thin section the difference is apparent from the smaller grain size of recrystallized quartz in $\mathrm{L}_{4}$ lineations, probably reflecting lower temperature conditions of deformation (Passchier \& Trouw, 1996). 


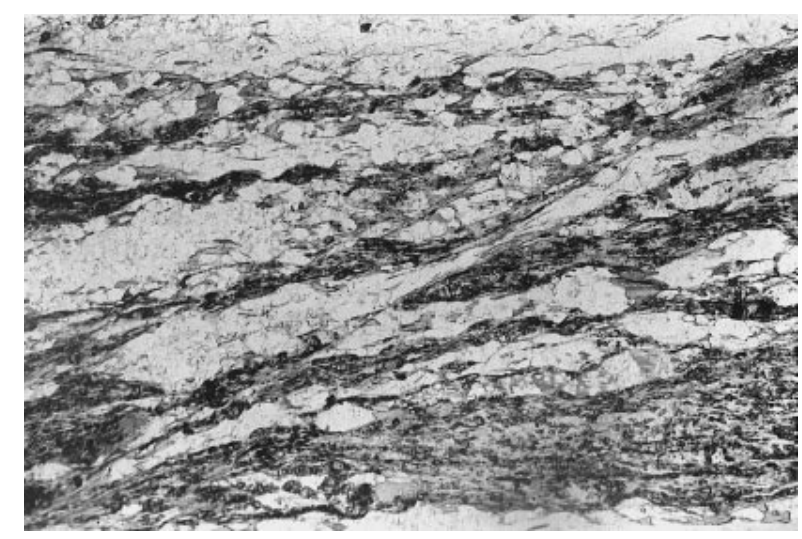

Figure 9. Photomicrograph of $\mathrm{D}_{4}$ shear bands in phyllite, indicating sinistral sense of shear. Station PO-2. Width of view 6 $\mathrm{mm}$. Plain polarized light.

$D_{5}$ is a phase of brittle faults and kink bands that are usually steeply dipping and which predominantly have east-west or north-south trend. They indicate mostly horizontal extension, although some constrictional faults have been observed as well. Station PO-1 is the link between the low grade southern part of Powell Island, where $S_{0}$ is well preserved, and the northern part where $S_{0}$ is transposed. At this station, $S_{0}$ and structures of all five deformation phases can be observed.

The structures on Powell Island were described by Dalziel (1984) as belonging to three deformational phases: an early phase, a main phase and a late phase. His early phase correponds to our $\mathrm{D}_{1}$, his main phase to our $\mathrm{D}_{2}$ and his late phase to our combined $\mathrm{D}_{3}, \mathrm{D}_{4}$ and $\mathrm{D}_{5}$.

Meneilly \& Storey (1986) reported a similar sequence of five deformation phases from Signy Island, interpreted by them to reflect tectonic transport of the hanging wall to the north or north-northwest, related to subduction in the opposite direction. No indication of normal movement with down-dip tectonic transport to the south is described by them; our observations from two outcrops on the south coast of Coronation Island, northeast of Signy Island (Fig. 1b), confirm the lack of such structures at these sites. It therefore seems that the south-directed, normal movements related to $\mathrm{D}_{4}$ are restricted to Powell Island. However, it is possible that such structures exist elsewhere on Coronation Island, which has not been investigated in detail.

In the lower grade rocks of southern Powell Island, the Whale Skerries and Fredriksen Island the structures are less regular and will therefore be described separately below. The main structure at Fredriksen Island is a penetrative cleavage, $S_{1}$, (sub)parallel to the well-preserved bedding $\mathrm{S}_{0}$, dipping predominantly to the west (Figs 2, 4). Few isoclinal small scale $(<1 \mathrm{~m}) \mathrm{D}_{1}$ folds with axes 290/10 show folded $S_{0}$ with $S_{1}$ along the axial surface. As shown in Figure 4, $\mathrm{S}_{0} / \mathrm{S}_{1}$ are folded in open to gentle folds with steep axial planes (250/90) and axes 354/10.

At the Whale Skerries, $S_{0}$ can also be clearly recognized with an $S_{1}$ cleavage at a small angle or subparallel to it.
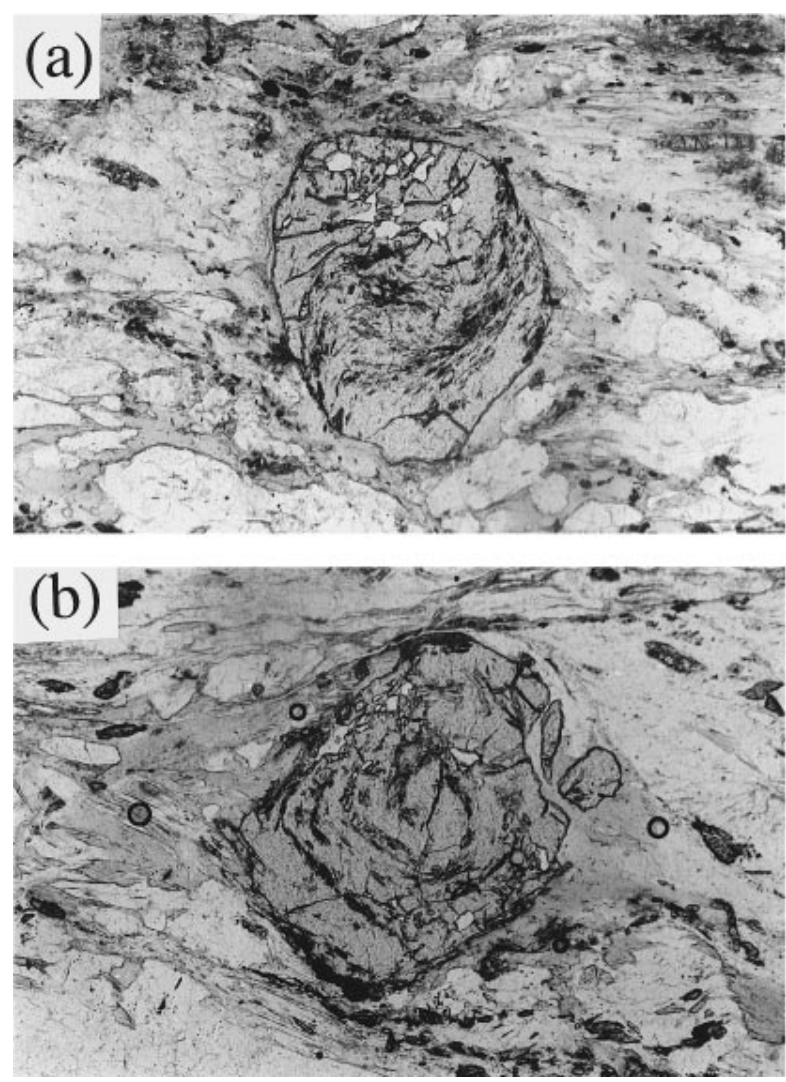

Figure 10. (a) Photomicrograph showing garnet crystal with an inclusion pattern interpreted as helicitic $\mathrm{D}_{2}$ folds; although $\mathrm{S}_{\mathrm{i}}$ is discontinuous with $\mathrm{S}_{\mathrm{e}}$ the garnet is interpreted to have grown during $\mathrm{D}_{2}$, since the $\mathrm{S}_{2}$ foliation in the matrix $\left(\mathrm{S}_{\mathrm{e}}\right)$ is deflected around the garnet. Station PO-5. Width of view $3 \mathrm{~mm}$. Plain polarized light. (b) Garnet crystal with a spiral inclusion pattern suggesting syntectonic growth; this may refer either to $\mathrm{D}_{1}$ or to $\mathrm{D}_{2}$. Station PO-6a. Width of view $3 \mathrm{~mm}$. Plain polarized light.

Some isoclinal small scale $\mathrm{D}_{1}$ folds have northwest-southeast trending axes. $S_{0}$ and $S_{1}$ are folded in large scale $(>10 \mathrm{~m})$ open folds with northwest-southeast axes and steep standing axial surfaces. A large number of steep faults with fault breccias and variable orientation result in a somewhat chaotic aspect of many outcrops.

\section{Comparison of structural evolution and metamorphism}

The relative growth period of metamorphic minerals with respect to the deformation phases is as follows. $\mathrm{S}_{2}$ surfaces show a strong deflection around garnet porphyroblasts (Fig. 10), indicating that these grew before or during $\mathrm{D}_{2}$. Inclusion patterns in garnet include apparent folds of an older foliation ( $\mathrm{S}_{1}$; Fig. 10a) and spiral shapes (Fig. 10b). The first pattern suggests garnet growth contemporaneous with $\mathrm{D}_{2}$, but the second may be explained both as syn- $\mathrm{D}_{1}$ and syn- $\mathrm{D}_{2}$ garnet growth. It can be concluded that garnet growth may have started during $\mathrm{D}_{1}$, was definitely in progress during $\mathrm{D}_{2}$, and stopped before the end of this phase (Fig. 11). The occurrence of epidote, calcite, albite and sphene inclusions within the 


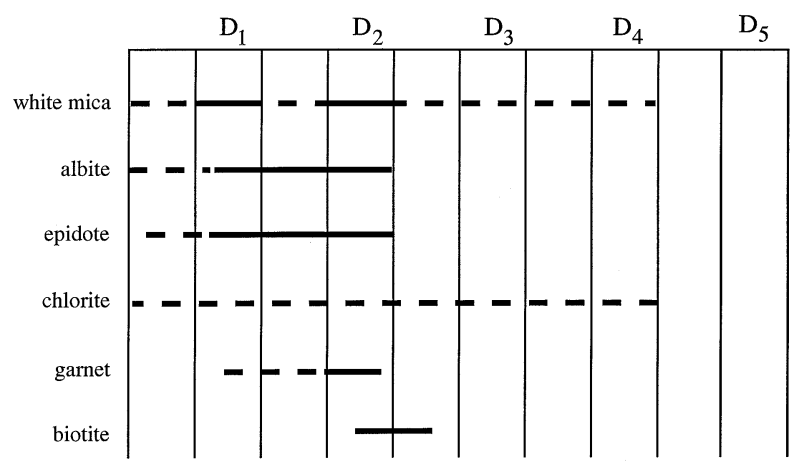

Figure 11. Growth periods of the main metamorphic minerals with respect to the deformation phases.

garnets demonstrates that the formation of these minerals preceded garnet growth, although partial contemporaneity cannot be excluded. The growth period of biotite is more difficult to interpret because this mineral did not form porphyroblasts nor does it occur as inclusions. However, local substitution textures suggest that biotite grew later than garnet. Figure 11 summarizes the relations and shows that peak metamorphic conditions were attained during $\mathrm{D}_{2}$, with deformation under retrograde conditions during the later phases.

\section{Age data}

Previously published age data from the Scotia metamorphic complex of the South Orkney Islands (all from Signy and Coronation islands) fall mainly in the range 176-205 Ma. Miller (1960) obtained K-Ar ages of $176 \mathrm{Ma}$ in muscovite and between 176 and $199 \mathrm{Ma}$ in biotite. Grikurov, Krylov \& Silin (1967) determined an age of 205 Ma for muscovite by the same method, and Tanner, Pankhurst \& Hyden (1982) published an age of around $190 \mathrm{Ma}$ for a hornblende separate, also determined by the $\mathrm{K}-\mathrm{Ar}$ method. Ar-Ar analysis in muscovite yielded an age of $184 \pm 4 \mathrm{Ma}$ (Grunow et al. 1992). However, a Rb-Sr 'errorchron' indicates a much older age of $281 \pm 56 \mathrm{Ma}$ (Tanner, Pankhurst \& Hyden, 1982; Rex, 1976).

The supposed Permo-Triassic age of the GreywackeShale Formation, based on its correlation with the Trinity Peninsula Group (Thomson, 1975) is supported by Triassic radiolarians reported by Dalziel et al. (1981) from an isolated chert occurrence at Scapa Rock (Fig. 1b), interpreted as part of the Greywacke-Shale Formation. $\mathrm{Rb}-\mathrm{Sr}$ isochron ages were reported by Pankhurst (1983; $281 \pm 16 \mathrm{Ma}$ ) for the Trinity Peninsula Group at Hope Bay and by Willan, Pankhurst \& Hervé (1994; $243 \pm 8$ Ma) for the supposedly correlative Miers Bluff Formation at Livingston Island, South Shetland Islands.

Trouw, Pankhurst \& Ribeiro (1997) obtained an 'errorchron' of $213 \pm 38 \mathrm{Ma}$ with MSWD of 12 from seven samples of deformed phyllites from Powell Island (station PO-7B; Fig. 2). A new whole rock $\mathrm{K}-\mathrm{Ar}$ age of $239 \pm 19 \mathrm{Ma}$ is reported here from an anchizone metamorphosed volcanic pebble in the diamictite at Fredriksen Island (FR-1-8A). Although this age conforms well with other ages obtained in this area, the potassium content of this pebble is relatively low $(0.0791 \%)$ and atmospheric Argon content is high $\left(\mathrm{Ar}_{\mathrm{atm}} 76.25 \%\right)$.

In the context of the geological relations outlined above, available radiometric and fossil ages are here interpreted as follows:

The sedimentation age of the Greywacke-Shale Formation is probably Triassic as indicated by the fossils from Scapa Rock (Dalziel et al. 1981), fossils from the Cape Legoupil area (Thomson, 1975) and by most of the $\mathrm{Rb}-\mathrm{Sr}$ isochrons from Greywacke-Shale Formation and equivalent units (Trinity Peninsula Group and Miers Bluff Formation). If the K-Ar age $(239 \pm 19 \mathrm{Ma})$ of the volcanic pebble mentioned above is interpreted as its crystallization age, the sedimentation of the Greywacke-Shale Formation must have occurred between about 200 (age of metamorphism) and 239 \pm 19 Ma. However, if this age is understood as representing metamorphism (improbable, because of the other metamorphic ages mentioned above), or a mixed value between metamorphism and crystallization, the sedimentation might have initiated before $239 \mathrm{Ma}$. The metamorphism of the Greywacke-Shale Formation and ocean floor material (see Section 9.a) at Signy and Coronation Islands probably occurred in the interval 176-205 Ma, as indicated by all $\mathrm{K}-\mathrm{Ar}$ mineral ages and by the $\mathrm{Ar}-\mathrm{Ar}$ data. The $\mathrm{Rb}-\mathrm{Sr}$ 'errorchron' from Powell Island $(213 \pm 38 \mathrm{Ma})$ with its large error could either reflect sedimentation or metamorphism or even represent a mixture of both. Trouw, Pankhurst \& Ribeiro (1997) interpreted it as a sedimentation age. By the late Jurassic (about $150 \mathrm{Ma}$ ) the metamorphosed sequences had been uplifted and were cropping out and eroding as testified by remnants of alluvial fans from this period with metamorphic detritus (Powell Island Conglomerate; Elliot \& Wells, 1982; Wells, 1984).

The Rb-Sr 'errorchron' of $281 \pm 56 \mathrm{Ma}$ from Coronation and Signy islands (Tanner, Pankhurst \& Hyden, 1982; Rex, 1976) and the similar isochron of $281 \pm 16$ (Pankhurst, 1983) from the Trinity Peninsula Group at Hope Bay, do not fit in the scheme presented above, and are difficult to explain. Similar values were reported from the Elephant Island group (Hervé et al. 1990, 1991; Trouw, Pankhurst \& Kawashita, 1990), South Shetland Islands, which is also part of the Scotia metamorphic complex; these were interpreted by Trouw, Pankhurst \& Kawashita (1990) as possibly due to the presence of relic radiogenic $\mathrm{Sr}$ from the source area.

\section{Discussion}

\section{9.a. Comparison with Coronation and Signy islands}

The interpretation of the Scotia metamorphic complex at northern Powell Island as a metamorphosed part of the Permo-Triassic Greywacke-Shale Formation raises the question as to what extent this interpretation is also valid 
for other parts of the Scotia metamorphic complex (Dalziel, 1982, 1984). Within the South Orkney Islands, the metamorphic sequence of northern Powell Island is certainly quite different from the sequence that crops out on Signy Island (Storey \& Meneilly, 1985) (Fig. 1b). Whereas the former is principally composed of continentderived turbidites, the latter contains a considerable percentage of metachert, marble and mafic rocks of ocean floor origin (Storey \& Meneilly, 1985). The data available from Coronation Island (Thomson, 1974) (Fig. 1b) show at least in part a close similarity to the ones from Signy Island. During our investigations four stations were visited on Coronation Island (Fig. 1b). Preliminary results suggest the existence of a gradual transition between predominantly ocean floor-derived sequences in the central part, to continent-derived submarine fan successions in the eastern part of the island. Hence, in the South Orkney Islands the equivalence between the 'Scotia metamorphic complex' and the Greywacke-Shale Formation is only valid for Powell Island and possibly for a small segment of eastern Coronation Island.

\section{9.b. Comparison with the South Shetland Islands}

Other parts of the Scotia metamorphic complex that crop out in the South Shetland Islands (Fig. 1a) have been interpreted as being, at least in part, derived from ocean floor material (Dalziel, 1984; Trouw, Pankhurst \& Kawashita, 1990; Grunow et al. 1992; Valeriano \& Heilbron, 1994). These parts have a similar composition and tectonic setting to the rocks on Signy and Coronation islands, but they yield different radiometric ages. Based on these ages a threefold subdivision of the complex has been proposed (Trouw, 1991; Trouw et al. 1994): the South Orkney Islands (180-220 Ma) and, in the South Shetland Islands, the Elephant Island group (80-120 Ma) and Smith Island (47-53 Ma).

The metamorphic sequence from Powell Island can only be correlated with metamorphic sequences from the South Shetland Islands in terms of a similar tectonic setting, related to the Pacific subduction zone of Gondwana. However, there are significant differences in protolith and in age of metamorphism. The Scotia metamorphic complex is a tectono-metamorphic unit rather than a litho-stratigraphic one and it may therefore include rocks of different ages and protoliths. However, the Greywacke-Shale Formation and its higher metamorphic equivalent on Powell Island are still comparable to the Trinity Peninsula Group on the Antarctic Peninsula, and to the Miers Bluff Formation in the South Shetland Islands.

\section{9.c. Mesozoic evolution of the South Orkney Microcontinent}

The Mesozoic evolution of the SOM has been regarded as relatively straightforward by previous authors. Dalziel (1984) described north-south trending lineations in the South Orkney Islands and attributed them to a subduction- related tectonic regime in the early Mesozoic. King \& Barker (1988) described a major graben south of the islands filled with $5 \mathrm{~km}$ of sediments, the Newton graben, as a basin associated with a fore-arc setting. Barker, Dalziel \& Storey (1991) interpreted the east-west trending structure of the islands, the presence of the Newton graben and an east-west trending magnetic anomaly south of this graben (Harrington, Barker \& Griffiths, 1972) as an accretionary prism, fore-arc spreading basin and magmatic arc triplet associated with south-directed subduction (in the present orientation). Our data show that the situation may be more complicated than suggested by any of these authors. Our $\mathrm{D}_{1}-\mathrm{D}_{3}$ structures on Powell Island, similar structures on Coronation Island and possibly the foliations on Fredriksen and Laurie islands are thought to be associated with south-directed (according to present coordinates) subduction in early to middle Jurassic times. Evidence for such south-directed subduction has also been found on Signy Island (Meneilly \& Storey, 1986). The close association of these structures with the relatively high pressure metamorphism suits this interpretation well. The dominant east-vergent asymmetry of $\mathrm{D}_{3}$ folds on Powell Island may be due to a gradual change in subduction direction during which older planar structures rotated into the shortening field, while stretching lineations kept developing without being refolded.

Our $\mathrm{D}_{4}$ structures have a similar direction but opposite shear sense to the subduction movement and are apparently associated with horizontal extension and uplift; $\mathrm{D}_{4}$ is a phase of ductile mylonitization at lower greenschist facies conditions and can be dated as middle to late Jurassic. By late Jurassic time, the entire sequence had been uplifted to the surface and was covered unconformably by terrestrial sediments (Thomson, 1981), as elsewhere throughout the Scotia arc region (Dalziel, 1984). Consequently, $\mathrm{D}_{4}$ is interpreted as an important phase of north-south crustal extension. The geometry of $\mathrm{D}_{4}$ shear bands suggests that the zone in which $\mathrm{D}_{4}$ structures formed was a stretching shear zone (Means, 1989), and such shear zones may be typical for large-scale crustal extension (Passchier, 1991).

$\mathrm{D}_{4}$ structures have so far only been found on Powell Island. Coronation, Powell, Fredriksen and Laurie islands represent blocks of different metamorphic grade and structural evolution. These differences may repesent various structural regimes that were present at different depths in the crust before uplift. During peak metamorphic conditions, Coronation Island may have been at a deeper crustal level than Powell Island, and Powell at a deeper level than any of the eastern islands (Fredriksen, Laurie and smaller islands). The fact that $\mathrm{D}_{4}$ ductile extensional structures are limited to Powell Island may indicate that they developed in a shear zone of limited width at the crustal level of Powell Island, above the level of Coronation Island and below that of Fredriksen, Laurie and the eastern islands. The differences in metamorphic grade between the islands may partly be due to juxtaposition during the extensional $\mathrm{D}_{4}$ event. 
(a) Triassic

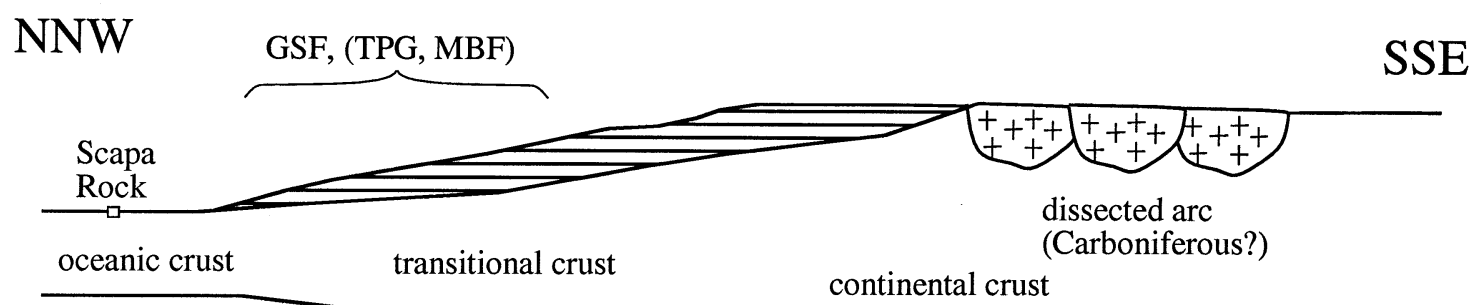

\section{(b) Early-Middle Jurassic}

\section{(c) Late Jurassic - Early Cretaceous}

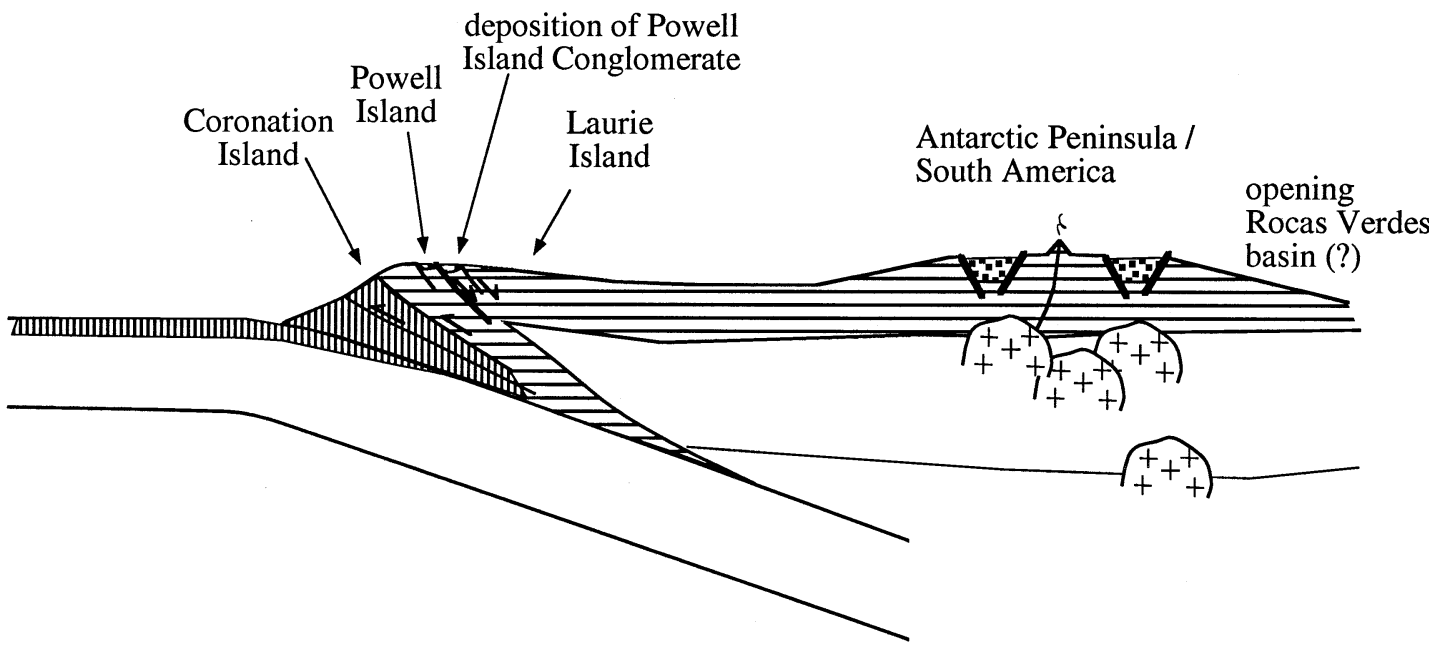

Figure 12. Tentative schematic reconstruction of the tectonic evolution of the South Orkney Islands. The relative rotation of the northern part of the Antarctic Peninsula and of the South Orkney Islands block with relation to Powell Basin from which it was torn off is not taken into consideration in this reconstruction. (a) Deposition of Greywacke-Shale Formation (GSF), Trinity Peninsula Group (TPG) and Miers Bluff Formation (MBF) in Triassic times along an inactive continental margin with a dissected arc in the source area. (b) Deformation and metamorphism of the rocks underlying Powell Island, related to the development of a subduction zone, during early to middle Jurassic times. The sequences of Coronation Island, mainly derived from ocean floor material (vertical striping), suffered metamorphism at the same time. (c) During late Jurassic-early Cretaceous times the rocks of Powell Island suffered extensional deformation followed by uplift and erosion. The Powell Island Conglomerate was deposited as alluvial fans. 
In their present orientation, the $\mathrm{D}_{4}$ structures on Powell Island are exposed on topographic levels where they should continue into the neighbouring islands. The fact that this is not the case shows that differential uplift along the major north-south trending extensional brittle faults, between and on the islands (Fig. 2), must also have played a (possibly minor) role in the present juxtaposition of the islands. These faults cut the conglomerates and may be associated with the separation of the SOM and the Antarctic Peninsula during development of the Scotia arc. The Newton graben has been interpreted as a forearc basin (King \& Barker, 1988), but could also be a $\mathrm{D}_{4}$ structure.

\section{9.d. Summary of evolution}

The tectonic evolution of the South Orkney Islands can now be summarized as follows (Fig. 12). In (Permo-)Triassic times, submarine fans accumulated along a probably inactive continental margin (Smellie, 1991; Doktor, Swierczewska \& Tokarski, 1994; Andreis, Ribeiro \& Trouw, 1997) next to a continent with a dissected magmatic arc (Fig. 12a). As discussed by other authors (e.g. Arche, Lopez Martínez \& Marfil, 1992; Smellie, 1991; Birkenmajer, 1992), this continent may have included southern South America. Subsequent subduction (early-middle Jurassic, 180-200 Ma) led to the metamorphism of part of the ocean floor and its cover (Scotia metamorphic complex) including part of the turbidites (Powell Island), accompanied by deformation $\left(\mathrm{D}_{1}\right.$, $\mathrm{D}_{2}$ and probably $\mathrm{D}_{3}$; Fig. 12b). Later extension (middle-late Jurassic) in the north-south direction with respect to the present position of the islands caused $D_{4}$ structures at Powell Island under retrograde metamorphic conditions related to uplift (Fig. 12c). These movements resulted by the end of Jurassic time in the exposure of the metamorphic sequence, as testified by remnants of alluvial fan deposits (Spence Harbour and Powell Island Conglomerate; Elliot \& Wells, 1982; Wells, 1984) of late Jurassic to early Cretaceous age (Fig. 12c). The final uplift and erosion in Cenozoic times was accompanied by brittle deformation $\left(\mathrm{D}_{5}\right)$ that affected the conglomerates as well.

\section{9.e. Regional geological implications}

Recent reconstructions of the southern Scotia arc have shown that relative movement between southern South America and the Antarctic Peninsula, eventually leading to separation of the SOM from adjacent continental fragments, started at about $100 \mathrm{Ma}$ (Grunow et al. 1992; Cunningham et al. 1995). With the possible exception of $\mathrm{D}_{5}$, the structures and metamorphism on Powell and neighbouring islands all pre-date deposition of the Powell Island Conglomerate in late Jurassic time, and therefore pre-date development of the Scotia arc. The significance of these early fabrics can be better assessed if later evolution of the SOM during development of the Scotia arc is considered. For this purpose, it is necessary to consider both the structures on the islands, and those on and around the submerged parts of the SOM.

The SOM has undergone considerable extension and is composed of an unusually thin crust (King \& Barker, 1988). King \& Barker (1988), Rodriguez-Fernandez et al. (1994) and King et al. (1994) investigated the structure of the submerged part of the SOM and its margins. They found dominant north-south trending faults and small sedimentary basins throughout the SOM, which represent east-west extension. These structures post-date east-west trending faults and the major east-west trending Newton graben south of the islands, which represents north-south extension.

The Powell Basin (Fig. 1a) has been presented as a small extensional oceanic basin that formed by east or northeast directed movement of the SOM away from the Antarctic Peninsula between 40 and 23 Ma (King \& Barker, 1988; King et al. 1994; Lawver, Williams \& Sloan, 1994). Strike-slip faults seem to bound the northwest side of the Powell Basin towards the South Scotia Ridge, while the southwest margin of the basin towards the Antarctic Peninsula appears to be of a transtensional nature (Fig. 1a; Rodriguez-Fernandez et al. 1994; Galindo-Zaldivar et al. 1994). The South Scotia Ridge is deformed by sinistral strike-slip faults that connect small extensional basins (Galindo-Zaldivar et al. 1994). Although no clear magnetic anomalies have been found on the oceanic floor of the Powell Basin, there is some indication of a northwest-southeast oriented spreading ridge (McAdoo \& Marks, 1992).

From the available offshore data it seems that the SOM was attached to the tip of the Antarctic Peninsula until approximately $40 \mathrm{Ma}$, and it then drifted eastward in response to major extension in the Powell Basin and in

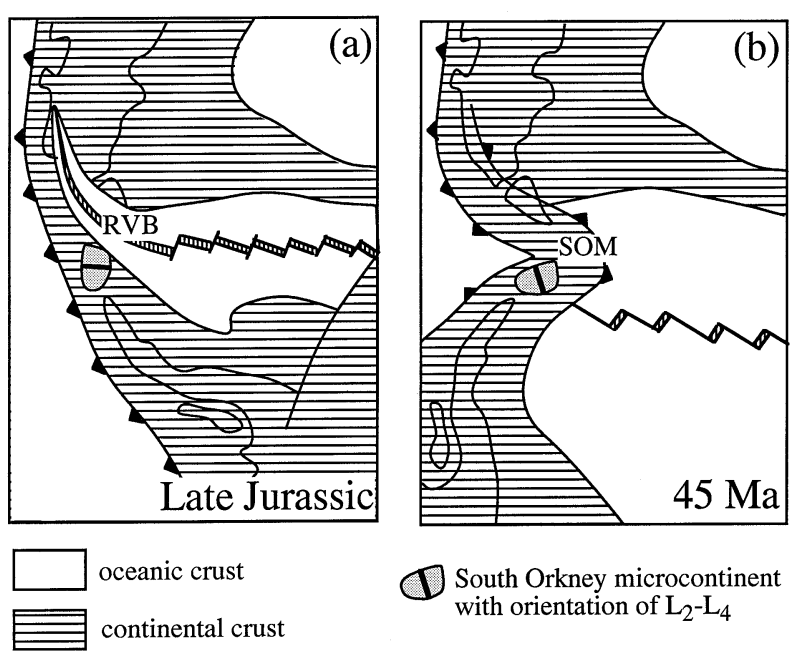

Figure 13. Schematic reconstruction of the Scotia arc region modified after Barker, Dalziel \& Storey (1991). (a) Late Jurassic; (b) 45 Ma. Symbols as in Figure 1a. Explanation in text. RVB - Rocas Verdes Basin; SOM - South Orkney Microcontinent. 
the microcontinent. Major north-south trending $\mathrm{D}_{5}$ extensional faults between and on the islands are probably of this age since they cut the conglomerates. The reconstruction of movement of the SOM during development of the Scotia arc indicates that it probably did not rotate much during its separation from the Antarctic Peninsula, but that it moved to the east or northeast along the South Scotia transform fault and another transcurrent fault bounding the SOM to the south. This implies that the north-south or northwest-southeast trending lineations on Powell Island and the gently plunging foliations were in approximately their present orientation at the onset of Scotia arc development.

\section{9.f. Implications related to the breakup of Gondwanaland}

The sequence of early constrictional and late extensional movements in a north-south direction on Powell Island can hardly be dismissed as a coincidence, especially since they are separated by a relatively limited time interval. $\mathrm{D}_{4}$ extension may be an effect of gravity collapse in a developing accretionary wedge (Fig. 12). Another possibility is that $D_{4}$ is an effect of the first stages of breakup of Gondwanaland that occured around this time (middle to late Jurassic). Reconstructions of the first opening between east and west Gondwana suggest that spreading did not interrupt the Pacific active continental margin that connected South America and the Antarctic Peninsula at the time, but that this spreading led to the formation of the Rocas Verdes Basin in southern South America (Fig. 13a) (Barker, Dalziel \& Storey, 1991). The extension observed in the SOM may therefore alternatively be associated with opening of the Rocas Verdes Basin (Fig. 13a). In late Jurassic time, the Antarctic Pensinsula and the still attached SOM have been reconstructed to lie approximately parallel to the coast of South America (Fig. 13a) (Barker, Dalziel \& Storey, 1991). In this orientation, the SOM would have been in a position somewhere between the Pacific continental margin and the proposed position of the Rocas Verdes Basin, and $\mathrm{L}_{2}-\mathrm{L}_{4}$ lineations would have been in a near east-west orientation, slightly oblique to both (Fig. 13a) (Barker, Dalziel \& Storey, 1991). $\mathrm{D}_{4}$ extension could have been directly related to the extension that created the Rocas Verdes basin on the internal part of the Pacific active margin.

King \& Barker (1988) and Barker, Dalziel \& Storey (1991) suggest that clockwise rotation of the Antarctic Peninsula with respect to South America in the latest Cretaceous, due to opening of the Weddell sea and the ocean between West and East Gondwana, caused north-south convergence in the Pacific margin of Gondwana to form a large-scale east-directed cusp-fold structure (Fig. 13b). The SOM would be located on the southern limb of this 'pre-Scotia cusp', opposite South Georgia. This rotation would have brought the SOM roughly into its present orientation, which it must have had around $40 \mathrm{Ma}$ (Fig. 13b; King \& Barker, 1988). Although the model sketched above is attractive, we found no structures that we could associate with this rotation of the SOM. If the rotation took place as envisaged by King \& Barker (1988) and Barker, Dalziel \& Storey (1991), deformation must have taken place along shear zones which happen to lie outside the presently exposed part of the SOM. The alternative model presented by Cunningham et al. (1995) seems to be in better agreement with the observed structures.

Acknowledgements. The Brazilian Antarctic Program, PROANTAR, is gratefully acknowledged for organizing and financing the field work. The Brazilian Research Council $(\mathrm{CNPq})$ financed the project and laboratory work. The following members of the project participated in field and laboratory work: Fabio V.P. Paciullo, Julio Cesar H. de Almeida and André Ribeiro. Students that helped with the description of thin sections are: Eduardo M.O. Castro, Neyma K. Azambuja, Marcelo Barone and Alexandre M.C. Silva. Microprobe analyses were realized at the Earth Science Department of Utrecht University, the Netherlands. The K-Ar age determination (SPK7232) was obtained from the GEOCRON laboratory from the State University at Sao Paulo (USP), Brazil. CWP gratefully acknowledges financial support by the Dutch Antarctic organization GOA. We thank Ian Dalziel and Bryan Storey for constructive criticism, leading to considerable improvement of the manuscript.

\section{References}

Andreis, R.R., Ribeiro, A. \& Trouw, R. A. J. 1997. Remarks on the petrofacies of Permo-Triassic turbidites from the Antarctic Peninsula, South Shetland and South Orkney islands. In The Antarctic Region: Geological Evolution and Processes (ed. C. A. Ricci), in press. Siena, Italy: Tipografia Senese.

Arche, A., Lopez-Martinez, J. \& MARFIL, R. 1992. Petrofacies and provenance of the oldest rocks in Livingston Island, South Shetland Islands. In Geologia de la Antartida Occidental 3 (ed. J. Lopez-Martínez), pp. 93-104. Congreso Geologico de España, Salamanca, Simposios T3, Salamanca.

BANNO, S. 1986. The high pressure metamorphic belts in Japan: a review. Memoir of the Geological Society of America 164, 365-74.

BARKER, A. J. 1991. Introduction to metamorphic textures and microstructures. London: Blackie, $170 \mathrm{pp}$.

Barker, P. F., Barber, P. L. \& King, E. C. 1984. An early Miocene ridge crest-trench collision on the South Scotia Ridge near $36^{\circ} \mathrm{W}$. Tectonophysics 102, 315-32.

BARKer, P. F. \& Burrell, J. 1977. The opening of Drake Passage. Marine Geology 25, 15-34.

BARKER, P. F., DAlZIEL, I. W. D. \& Storey, B. C. 1991. Tectonic evolution of the Scotia Arc region. In Antarctic Geology (ed. R. J. Tingey), pp. 215-48. Oxford: Oxford University Press.

British ANTARCTIC SURVEY. 1988. Topographic Map B.A.S. 100, Sheet South Orkney Islands (provisional, part of SP 23-24/1,2). Edition 1-1988. Scale 1: 100.000. Cambridge, England: Antarctic Survey.

Birkenmajer, K. 1992. Trinity Peninsula Group (PermoTriassic ?) at Hope Bay, Antarctic Peninsula. Polish Polar Research 13, 215-40.

Cunningham, W. D., Dalziel, I. W. D., Lee, T. Y. \& LaWver, L. A. 1995. Southernmost South America-Antarctic Peninsula relative plate motion since $84 \mathrm{Ma}$ : Implications for the tectonic evolution of the Scotia Arc region. Journal of Geophysical Research 100, 8257-66. 
Dalziel, I. W. D. 1982. The pre-Jurassic history of the Scotia arc: a review and progress report. In Antarctic Geoscience (ed. C. Craddock), pp. 111-26. Madison: University of Wisconsin Press.

DALZIEL, I. W. D. 1984. Tectonic evolution of a forearc terrane, southern Scotia ridge, Antarctica. Geological Society of America Special Paper no. 220, 32 pp.

Dalziel, I. W. D., Elliot, D. H., Jones, D. L., Thomson, J. W. Thomson, M. R. A., Wells, N. A. \& Zinsmeister, W. J. 1981. The geological significance of some Triassic microfossils from the South Orkney Islands, Scotia Ridge. Geological Magazine 118, 15-25.

DiCKINSON, W. R. 1985. Interpreting provenance relations from detrital modes of sandstones. In Provenance of Arenites (ed. G. G. Zuffa), pp. 333-61. Dordrecht: Reidel Publishing Co.

DiVenere, V., Kent, D. V. \& Dalziel, I. W. D. 1996. Summary of palaeomagnetic results from West Antarctica: implications for the tectonic evolution of the Pacific margin of Gondwana during the Mesozoic. In Weddell Sea Tectonics and Gondwana Break-up (eds B. C. Storey, E. C. King and R. A. Livermore), pp. 31-43. Geological Society of London, Special Publication no. 108.

Doktor, M., Swierczewska, A. \& Tokarski, A. K. 1994. Lithostratigraphy and tectonics of the Miers Bluff Formation at Hurd Peninsula, Livingston Island (West Antarctica). Studia Geologica Polonica 104, 41-104.

Elliot, D. H. \& Wells, N. A. 1982. Mesozoic alluvial fans of the South Orkney Islands. In Antarctic Geoscience (ed. C. Craddock), pp. 235-44. Madison: University of Wisconsin Press.

Galindo-Zaldivar, J., Jabaloy, A., Maldonado, A. \& SAnZ DE Galdeano, P. 1994. Transtensional deformation and internal basin evolution in the South Scotia Ridge. Terra Antarctica 1, 303-6.

Grikurov, G. E., KrYlov, A. Y. \& Silin, Y. I. 1967. Absolute age of some rocks from the Scotia arc and Alexander I land (western Antarctica). Akademiya Nauk SSSR Doklady, Earth Sciences Section (English translation), 19-22.

Grunow, A. M., Dalziel, I. W. D., Harrison, T. M. \& HEIZLER, M. T. 1992. Structural geology and geochronology of subduction complexes along the margin of Gondwanaland: New data from the Antarctic Peninsula and southernmost Andes. Bulletin of the Geological Society of America 104, 1497-1514.

GuidotTi, C. V. \& SAssi, F. P. 1986. Classification and correlation of metamorphic facies series by means of muscovite $\mathrm{b}_{\mathrm{o}}$ data from low-grade metapelites. Neues Jahrbuch für Mineralogie, Abhandlungen 153, 363-80.

HALPERN, M. 1965. The geology of the General Bernardo O'Higgins area, northwest Antarctic Peninsula. In Geology and Paleontology of the Antarctic (ed. J. B. Hadley), pp. 177-209. Antarctic Research Series no. 6. Washington, D.C.: American Geophysical Union.

Harrington, H. J., Barker, P. F. \& Griffiths, D. H. 1972. Crustal structure of the South Orkney Islands area from seismic refraction and magnetic measurements. In Antarctic geology and geophysics - symposium on Antarctic geology and solid earth geophysics. Oslo, 6-15 August 1970 (ed. R. J. Adie), pp. 27-32. Oslo: Universitetsvorlaget Oslo.

Hervé, F., Miller, H., Loske, W., Milne, A. \& Pankhurst, R. J. 1990. New Rb-Sr age data on the Scotia Metamorphic Complex at Clarence Island, west Antarctica. In Workshop on Antarctic Geochronology (ed. H. Miller), pp. 119-126. Zentralblatt für Geologie und Paläontologie, Teil I.
Hervé, F., Loske, W. P., Miller, H. \& Pankhurst, R. J. 1991. Chronology of provenance, deposition and metamorphism in the southern limb of the Scotia Arc. In Geological Evolution of Antarctica (eds M. R. A. Thomson, J. A. Crame and J. W. Thomson), pp. 429-435. Cambridge: Cambridge University Press.

King, E. C. \& BARKeR, P. F. 1988. The margins of the South Orkney Microcontinent. Journal of the Geological Society of London 145, 317-31.

King, E. C., Leitchenkov, G., Galindo-Zaldivar, J. \& Maldonado, A. 1994. Basement distribution in Powell Basin: Understanding the tectonic controls on sedimentation. Terra Antartica 1,307-8.

King, E. C., Livermore, R. A. \& Storey, B. C. 1996. Weddell Sea tectonics and Gondwana break-up: an introduction. In Weddell Sea Tectonics and Gondwana Break-up (eds B. C. Storey, E. C. King and R. A. Livermore), pp. 1-10. Geological Society of London, Special Publication no. 108.

KISCH, H. 1990. Calibration of the anchizone: a critical comparison of illite "crystallinity" scales used for definition. Journal of Metamorphic Petrology 8, 31-46.

Lawver, L. A., Della Vedova, B. \& von Herzen, R. P. 1991. Heat flow in the Jane basin, Northwest Weddell Sea. Journal of Geophysical Research 96, 2019-38.

Lawver, L. A., Williams, T. \& Sloan, B. 1994. Seismic stratigraphy and heat flow of the Powell basin. Terra Antarctica 1, 309-10.

LE MAITRE, R. W. 1989. A Classification of Igneous Rocks and Glossary of Terms. Oxford: Blackwell, $193 \mathrm{pp}$.

MAssone, H. J. \& SCHREYeR, W. 1987. Phengite geobarometry based on the limiting assemblage with K-feldspar, phlogopite, and quartz. Contributions to Mineralogy and Petrolology 96, 212-24.

Mcadoo, D. C. \& Marks, K. M. 1992. Gravity fields of the Southern Ocean from Geosat data. Journal of Geophysical Research 97, 3247-60.

Means, W. D. 1989. Stretching faults. Geology 17, 893-6.

Meneilly, A. W. \& Storey, B. 1986. Ductile thrusting within subduction complex rocks on Signy Island, South Orkney Islands. Journal of Structural Geology 8, 457-72.

MilleR, J. A. 1960. Potassium-argon ages of some rocks from the South Atlantic. Nature 187, 1019-20.

Nitsch, K. H. 1970. Experimentelle Bestimmung der oberer Stabilitätsgrenze von Stilpnomelan. Fortschritte der Mineralogie 47, 48-9.

Paciullo, F. V. P., Andreis, R. R. \& Ribeiro, A. 1994. Facies association of Hope Bay Formation at Hope Bay, Antarctic Peninsula. In 38 Congresso Brasileiro de Geologia, pp. 342-3. Balneario Camboriu, Boletim de Resumos Expandidos 1.

PANKhURST, R. J. 1983. Rb-Sr constraints on the ages of basement rocks of the Antarctic Peninsula. In Antarctic Earth Science (eds R. L. Oliver, P. R. James and J. B. Jago), pp. 367-71. Cambridge: Cambridge University Press.

PAsschier, C. W. 1991. Geometric constraints on the development of shear bands in rocks. Geologie en Mijnbouw 70, 203-11.

Passchier, C. W. \& Trouw, R. A. J. 1996. Microtectonics. Berlin: Springer Verlag. 289 pp.

Rex, D. C. 1976. Geochronology in relation to the stratigraphy of the Antarctic Peninsula. British Antarctic Survey Bulletin 43, 49-58.

Ribeiro, A., Andreis, R. R., Paciullo, F. V. P. \& Trouw, R. A. J. 1994. Triassic (?) submarine fan at Cape Legoupil, Antarctic Peninsula. In 38 Congresso Brasileiro de 
Geologia, pp. 367-8. Balneario Camboriu, Boletim de Resumos Expandidos 1.

RodrigueZ-FernandeZ, J., BALANya, J. C., GalindoZaldivar, J. \& MaLdONADO, A. 1994. Margin styles of Powell Basin and their tectonic implications (NE Antarctic Peninsula). Terra Antarctica 1, 315-16.

SMELLIE, J. L. 1991. Stratigraphy, provenance and tectonic setting of (?)late Palaeozoic-Triassic sedimentary sequences in northern Graham Land and South Scotia Ridge. In Geological Evolution of Antarctica (eds M. R. A. Thomson, J. A. Crame and J. W. Thomson), pp. 411-17. Cambridge: Cambridge University Press.

Smellie, J. L. \& Clarkson, P. D. 1975. Evidence for preJurassic subduction in western Antarctica. Nature 258, 701-2.

Storey, B. \& Meneilly, A. W. 1983. Mélange within subduction-accretion complex rocks of Fredriksen Island, South Orkney Islands. Geological Magazine 120, 555-66.

Storey, B. \& Meneilly, A. W. 1985. Petrogenesis of metamorphic rocks within a subduction-accretion terrane, Signy Island, South Orkney Islands. Journal of Metamorphic Geology 3, 21-42.

Tanner, P. W. G., Pankhurst, R. J. \& Hyden, G. 1982. Radiometric evidence for the age of the subduction complex in the South Orkney and South Shetland Islands, West Antarctica. Journal of the Geological Society, London 139, 683-90.

Thomson, J. W. 1973. The geology of Powell, Christoffersen and Michelsen islands, South Orkney Islands. British Antarctic Survey Bulletin 33-34, 137-67.

Thomson, J. W. 1974. The geology of the South Orkney Islands, III: Coronation Island. British Antarctic Survey Report 86, $1-39$.

Thomson, M. R. A. 1975. New paleontological and lithological observations in the Legoupil Formation, northwest Antarctic Peninsula. British Antarctic Survey Bulletin 41, 169-85.

Thomson, M. R. A. 1981. Late Mesozoic stratigraphy of the South Orkney Islands. British Antarctic Survey Bulletin 54, 65-83.

Trouw, R. A. J. 1991. A new subdivision of the Scotia metamorphic complex. In VI International Symposium of Antarctic Earth Sciences, Tokyo, pp. 622-3. Abstracts Volume. Tokyo: National Institute of Polar Research.
Trouw, R. A. J., Pankhurst, R. J. \& Kawashita, K. 1990. New radiometric age data from Elephant Island, South Shetland Islands. In Workshop on Antarctic Geochronology (ed. H. Miller), pp. 105-18. Zentralblatt für Geologie und Paläontologie, Teil 1.

Trouw, R. A. J., Ribeiro, A. \& Paciullo, F. V. P. 1991. Structural and metamorphic evolution of the Elephant Island group and Smith Island, South Shetland Islands. In Geological Evolution of Antarctica (eds M. R. A. Thomson, J. A. Crame and J. W. Thomson), pp. 423-8. Cambridge: Cambridge University Press.

Trouw, R. A. J., Ribeiro, A., Paciullo, F. V. P., Simões, L. S. A., Valeriano, C. M., Heilbron, M. \& Valladares, C. 1994. The Scotia metamorphic complex - a critical reappraisal. In 38 Congresso Brasileiro de Geologia, pp. 362-3. Balneario Camboriu, Boletim de Resumos Expandidos 1.

Trouw, R. A. J., Pankhurst, R. J. \& Ribeiro, A. 1997. On the relation between the Scotia metamorphic complex and the Trinity Peninsula Group, Antarctic Peninsula. In The Antarctic Region: Geological Evolution and Processes (ed. C. A. Ricci), in press. Siena, Italy: Tipografia Senese.

Valeriano, C. M. \& Heilbron, M. 1994. Lithogeochemical evidence for metamorphosed ocean floor basalts from Elephant Island, South Shetland Islands, Antarctica. In 7 Congreso Geologico Chileno, Concepción, Chile, Actas 2, pp. 1024-8. Universidad de Concepcion, Departamento Ciencias de la Tierra.

VALLONI, R. 1985. Reading provenance from modern marine sands. In Provenance of Arenites (ed. G. G. Zuffa), pp. 309-32. Dordrecht: Reidel Publishing Co.

WeLLS, N. A. 1984. Sheet debris flow and sheetflood conglomerates in Cretaceous cool-maritime alluvial fans, South Orkney Islands, Antarctica. In Sedimentology of Gravels and Conglomerates (eds E. H. Koster and R. J. Steel), pp. 133-45. Canadian Society of Petroleum Geologyn Memoir no. 10

Willan, R. C. R., Pankhurst, R. J. \& Hervé, F. 1994. A probable Early Triassic age for the Miers Bluff Formation, Livingston Island, South Shetlands Islands. Antarctic Science 6, 401-08.

YARDLEY, B. W. 1989. An introduction to metamorphic petrology. London: Longman, $248 \mathrm{pp}$. 